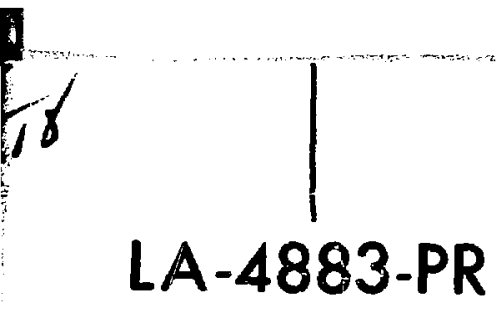

\title{
A PROGRESS REPORT
}

\section{Nuclear Analysis \\ Research and Development}

\author{
Program Status Report \\ September - December 1971
}


This report was prepared as an account of work sponsored by the United States Government. Neither the United States nor the United States Atomic Energy Commission, nor any of their employees, nor any of their contractors, subcontractors, or their employees, makes any warranty, express or implied, or assumes any legal liability or responsibility for the acuuracy, completeness or usefulness of any information, apparatus, product or process disclosed, or represents that its use would not infringe privatefy owned rights.

In the interest of prompt distribution, this progress report was not edited by the Technical Information staff.

Printed in the United States of America. Available from National Technical Information Service

U. S. Department of Commerce 5285 Port Royal Road

Springfield, Virginia 22151

Price: Printed Copy \$3.00; Microfiche \$0.95 
LA-4883-PR

A Progress Report

UC.15

ISSUED: March 1972

\title{
Nuclear Analysis
}

\section{Research and Development}

\author{
Program Status Report \\ September - December 1971
}

Nuclear Analysis Research Group, A-1

G. Robert Keepin, Group Leader

-NOTICR

This report we propared as an eceount of mork

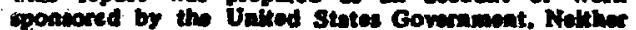
tho United Sthtes nor the United States Atomic Eanry Cosumitalon, nor eny of thit employew, sor way of thwir contraction, subcontsectore, of ther inployece,

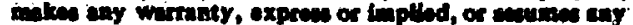

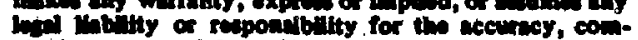

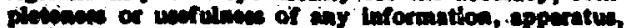

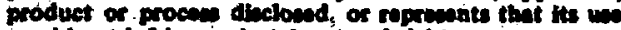

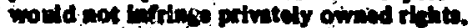




\section{CONTENTS}

I. NEUTRON INTERROGATION AND NONDESTRUCTIVE ASSAY OF FIS-

SIONABLE MATERIALS $\ldots \ldots \ldots \ldots \ldots \ldots \ldots \ldots \ldots \ldots \ldots \ldots$

A. Investigation of Sampling/Chemical Assay Using Nondestructive Assay Tech-

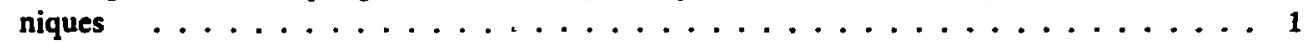

B. Subthreshold Neutron Interrogation System for Assay of Small Samples . . . . . . . 2

C. Measurement of the LASL Enriched Uranium Inventory . . . . . . . . . . . 3

D. Fissile Assay of Uranium-Thorium-Fluoride in Two-Liter Containers . . . . . . . . 4

E. Assay of Two-Liter Containers of Uranium-Thorium-Carbide . . . . . . . . . . . 4

II. MATERIALS ANALYSIS USING ISOTOPIC SOURCES $\ldots \ldots \ldots \ldots \ldots \ldots$

A. In-plant Performance of ${ }^{2 s 2} \mathrm{Cf}$ Fuel Rod Assay Systems . . . . . . . . . . . . 5

B. Thermal ${ }^{252} \mathrm{Ci}_{i}$ Fuel Rod Assay System with Pellet-to-Pellet Scan . . . . . . . . . . 6

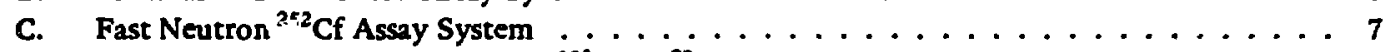

D. Photoneutron Assay system Using ${ }^{124}$ Sb or ${ }^{88} \mathbf{y} \ldots \ldots \ldots \ldots \ldots \ldots \ldots \ldots \ldots$

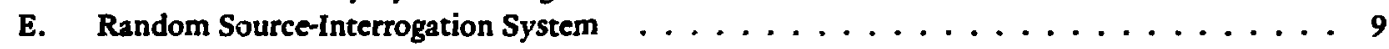

III. GAMMA-RAY AND X-RAY ANALYSIS APPLICATIONS $\ldots \ldots \ldots \ldots \ldots \ldots$

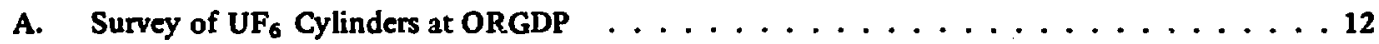

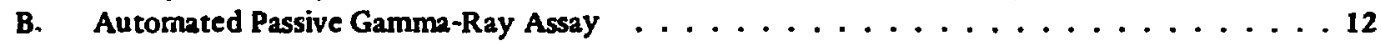

C. Trace Element Analysis Using X Ray and Proton-Induced X-Ray Fluorestence . . . . . 12

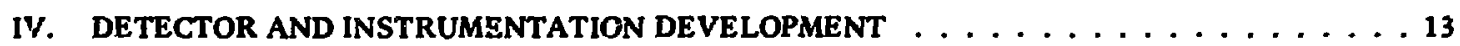

A. Sealed-Tube Neutron Generator Evaluation $\ldots \ldots \ldots \ldots \ldots \ldots$

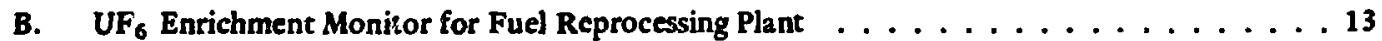

C. Coincidence Assay Systems for LASL Pu Processing Facility (DP-Site) $\ldots \ldots \ldots$

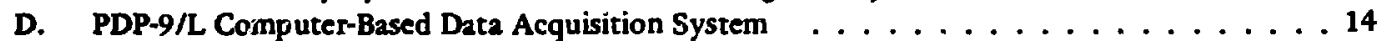

E. LASL Interactions with Commercial Manufacturers of Nondestructive Assay

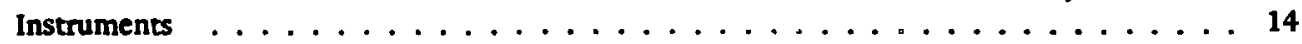

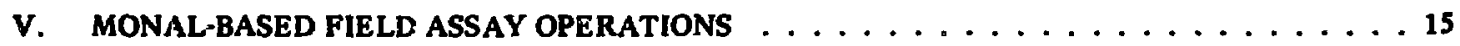

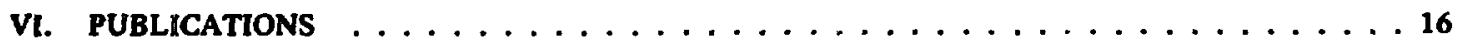




\section{NEUTRON INTERROGATION AND NONDESTRUCTIVE ASSAY OF FISSIONABLE MATERIALS}

A. Investigation of Sampling/Chemical Assay Using Nondestructive Assay Techniques-(J. H. Menzel, A. C. Dumrose (CMB-8), and R. H. Augistson)

This continuing investigation has focused on comparative nondestructive assay and sampling/chemical assay of an entire inventory ( 1502 -gal cans) of organic ash, a fine powder resulting from incineration and milling of nongraphite combustible scrap and fitters. The organic ash contains nominally $10 \%$ uranium $\left(93 \%{ }^{235} \mathrm{U}\right), 10 \%$ silicon, few-percent levels of nonvolatile elements between boron and zinc, and for the balance, bound oxygen. The standard assay procedures for this inventory called for blending and wet chemical analysis of grab samples. Nondestructive assay of the recovery cans was accomplished by the neutron interrogation/delayed-neutron response technique using a range of $\mathrm{U}_{3} \mathrm{O}_{8}$-graphite standards. A comparison of these assay results is shown in Fig. 1.

Selected results on 9 cans for which the nondestructive and sampling/chemical assay differed by either more than $100 \mathrm{~g} \mathrm{U}$ or more than $20 \%$, have been discussed previously. 1,2 In every case, reanalysis by sampling/chemical assay differed considerably from the original chemical analysis and agreed within $\sim 10 \%$ with nondestructive assay of the whole recovery can; i.e., with reference to Fig. 1, the percent difference moved from

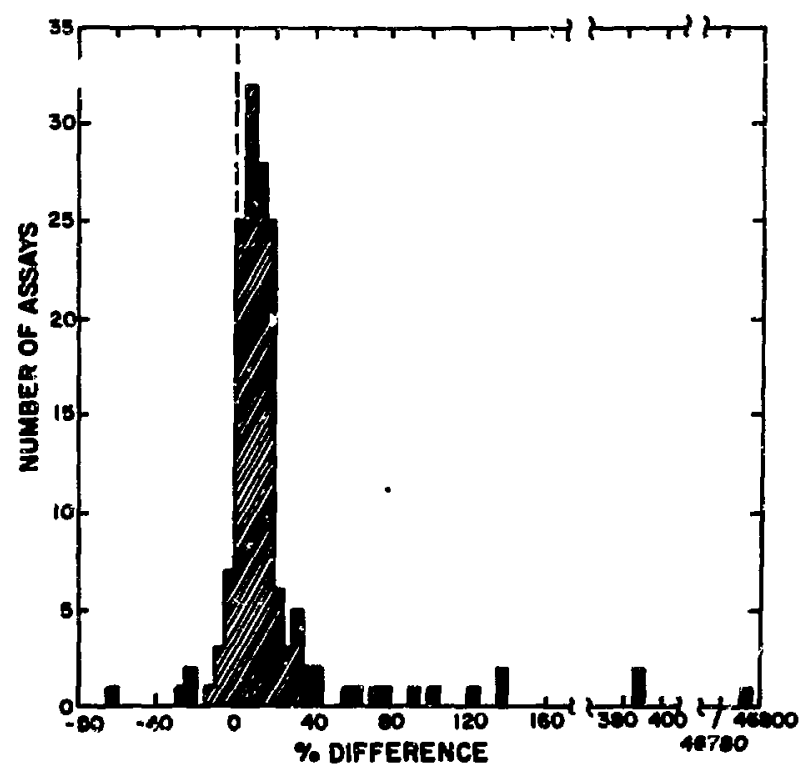

Fig. 1.

Comparison of nondestructive (N) and sams pling/cibemical (S) results, wliere $\%$ difference $=100$ (N-S)/S. the "wings" to the 20\%-wide peak. Unfortunately, however, to date it has not been possible to identify unequivocally the cause, or causes, of the original erroneous results obtained by sampling/chemical assay.

In addition to the gross differences discussed above, Fig. 1 clearly shows a positive bias of approximately 10\%; in other words, the nondestructive asay resules are $\sim 10 \%$ higher than the sampling/chemical assay values. Consequently, a set of eight recovery-ean $\mathrm{U}_{3} \mathrm{O}_{8}$-ingraphite standards, also $93 \%{ }^{235} \mathrm{U}$ enriched, was used to re-evaluate the response of the active interrogation system. The mean and standard deviation of three measarements on each standard are plotted in Fig. 2. A1/ $\sigma^{2}$-weighted lestsquares linear fit to the data shows that the relative response is indeed linear up to $1600 \mathrm{~g}$ of uranium with a correlation coefficient equal to 0.9998 , and that the response of the standards is $94.8 \pm 2.2$ per $\mathrm{g} \mathrm{U}$.

In order to check for a possible bias cunsed by matrix differences, the responze of two cans of organic ash "spiked" with kncwn amounts of uranium $(223 \mathrm{~g}$ and $539 \mathrm{~g}$ ) was measured and found to be $95.9 \pm 2.0$ per $\mathrm{g}$ uranium. The good agreement of this relative response with that shown in Fig. 2 indicates the lack of a significant bias between nondestructive assay of the graphite standards and the "spiked" organic ach standards-end thus the entire organic ash inventory, if it can be confirmed that "spiked" standards are indeed representative

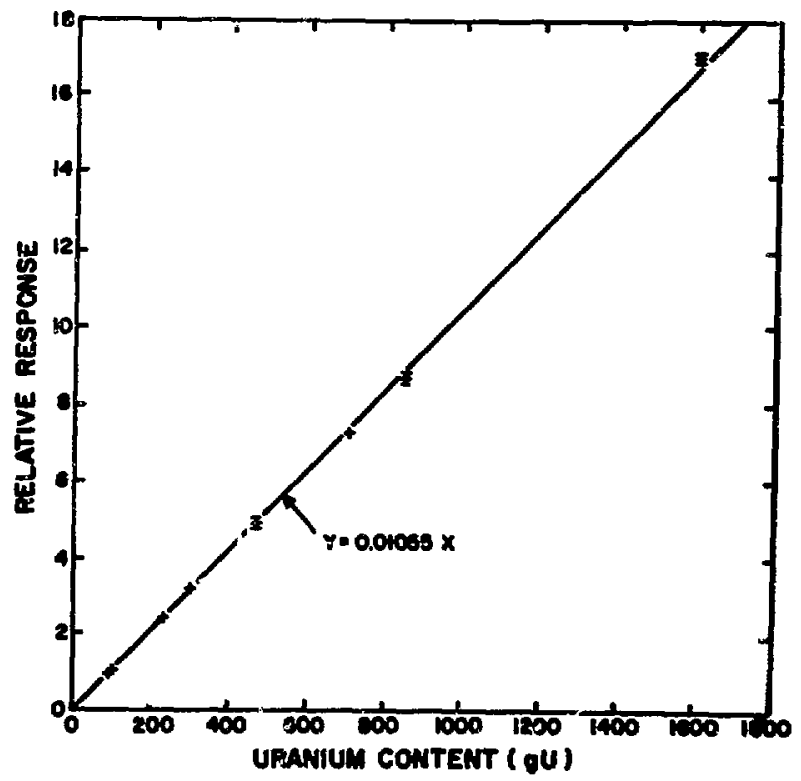

Fig. 2.

Neutron interrogation response curve exing recowry can $\mathrm{U}_{3} \mathrm{O}_{3}$-ingrapbite stundards. 
of the inventory. It is this latter point, particularly with r-gard to possible moisture content, which still has to be verified in detail. Also to be determined is the source of the significant spread of the peak frequency distribution plotted in Fig. 1.

To date, this investigation has clearly shown that the neutron interrogation/delayed-neutron yield method of nondestructive assay provides a rapid, reliable, and relatively inexpensive means for SS-inventory measurements of large quantities of scrap held for recovery, i.e.s compliance within the COEI* 171 (SS-value known to $\pm 10 \%$ ) reporting cote (see Sec. 1-C). However, much work needs to be done to determine definitively the cause of gross errors in sampling/chemical assay, the source of the observed $\sim 10 \%$ bias, and the accuracy and precision of all factors, particularly blending and sampling processes, entering into the uranium content analysis of recoverable serao.

B. Subthrechold Neutron Interrogation System for Assay of Small Samples (A. E. Evans, M. M. Thorpe, and J. J. Malanify)

Significant progress has been made in LASL's continuing program of improving the accuracy of smallsample fissile assay by the delayed-neutron response method. This method involves interrogation with subthreshold neutrons produced by the A-1 Van de Granff accelerator; it was found that assay results were exces. sively matrix-dependent due to the presence of epicadmium, resonance-region neutrons in the interrogating spectrum. To eliminate the resulting undesired neutron absorption effects in the sample, a small-sample assay chamber was designed and built incorporating a 3/4-in.thick shicld of hot-pressed boron carbide. This shield, consisting of a cylinder $2 \frac{2}{2}$-in. i.d. by 4 in. o.d. by $53 / 8$-in. long, plus two end caps $2 \%$-in. diam by $3 / 4$ in. thick, was fabricated by the Powder Metallurgy Section, Group CMB-6, LASL. The assay chamber is shown in Fig. 3. The sample luolder and shield are firmiy fastened to a standard A-1 "slab detector" used to measure delayed-neutron response. In Fig. 3 the accelerator target is seen at the left of the $\mathrm{B}_{4} \mathrm{C}$ cylindrical shield. Three-in. iron reflectors are normally positioned on either side of the neutron source and assay chamber; the nearside reflector bas been removed for the photogreph.

$A$ closeup of the assay chamber with the $B_{4} C$ shield and inner cadmium liner removed is shown in Fig. 4. Two fission chambers are seen in front of, and behind, the sample; these are used to monitor the interrogating neutron flux. The sample vial is held in an buminum sleeve which rciates at $10 \mathrm{rpm}$. Provision has been made to accomodate vials up to 1 in. diam.

The system was tested for linearity and matrixindependence using 1-dram vials containing from 0.25 to

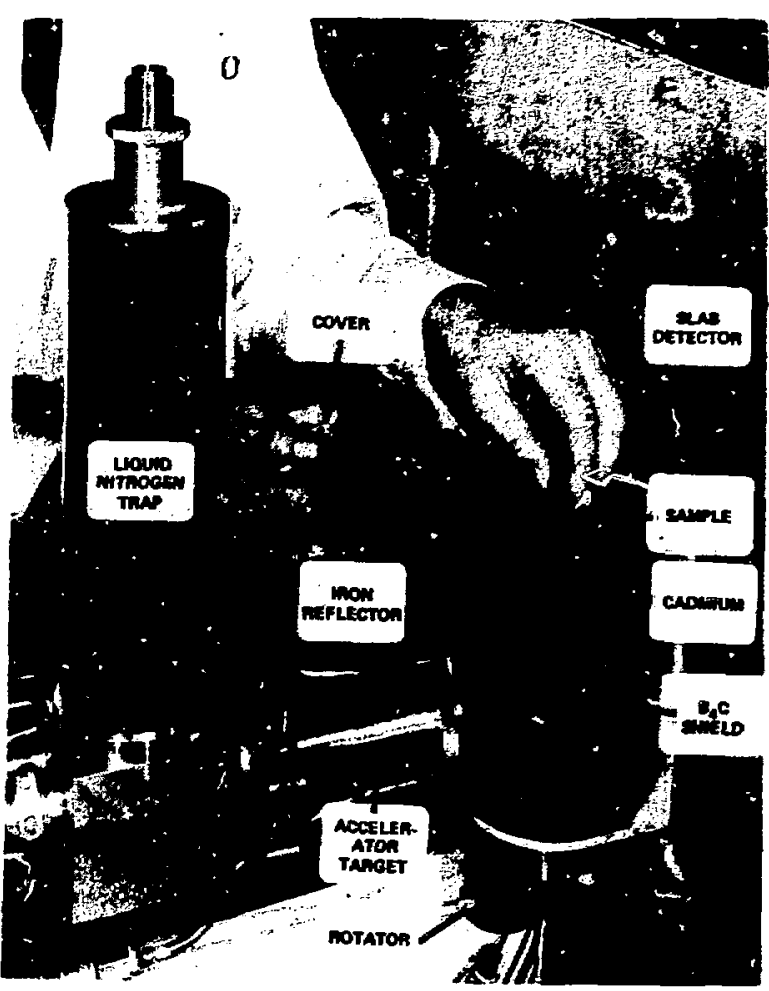

Fig. 3.

Small-sample assay chamber being used to assay gram-size samples.

$10 \mathrm{~g}$ of uranium $\left(93.17 \%{ }^{235} \mathrm{U}\right)$ in the form of pure oxide, plus vials containing $1 \mathrm{~g}$ of enriciled urani" $n$ mixed with varying quantities of aluminum or graphite. The results are shown in Figs. 5 and 6, together with earlier results ${ }^{3}$ obtained using the same samples with only cadmium shielding surrounding the sample and fission chambers; the rarlier measurements were made with and without a 3/4-in. Boral sheet between the samiple and the slab detector. A considerable improvement in linearity of response is apparent, extending up to at least $5 \mathrm{~g}$ of ${ }^{235} \mathrm{U}_{5}$ similarly good matrix independence is achieved for the cases studied.

Progress has also been made in the area of automated data handling. Scaler outputs for each run are read out on punched paper tape and a teletype printout. Group A-1's PDP-9/L computer is being programmed to process these tapes and print out the final assay results. When interfaced with appropriate automated samplechanging apparatus, the A-1 small-sample assay system will enable accurate routine nondestructive assay of quality control and inventory verification samples. This high-throughput, high-accuracy assay station for small samples will constitute an important NDA capability in LASL's projected Nondestructive Assay and Standards Laboratory.

- CoEt = composition of ending inventory. 


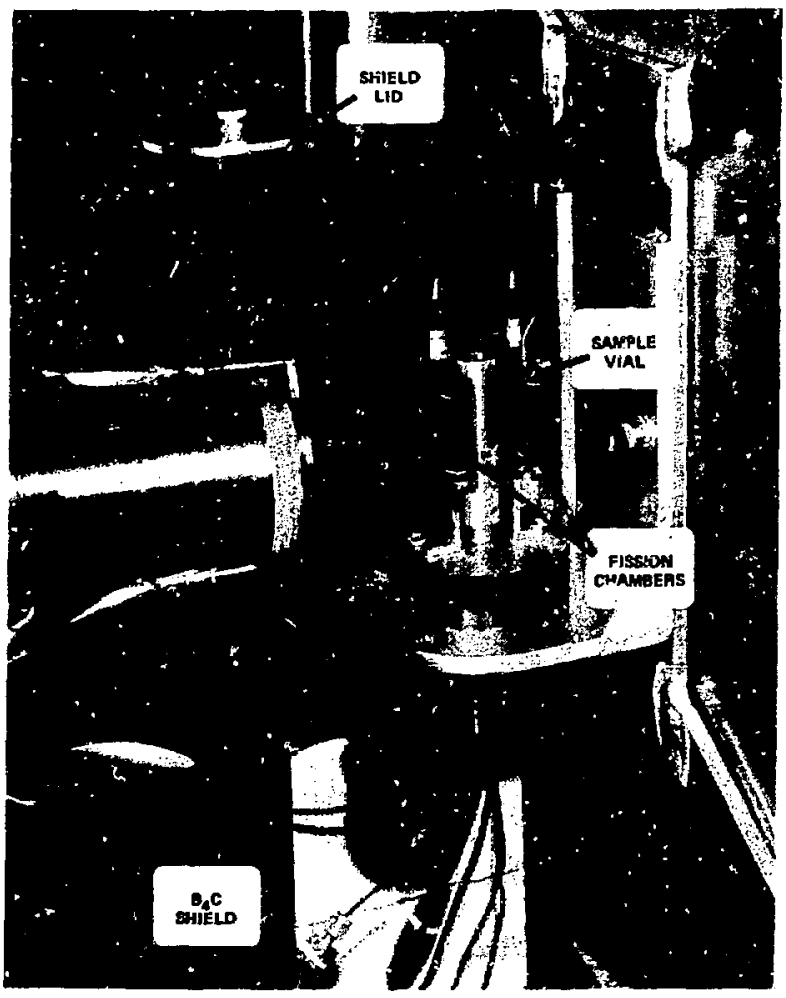

Fig. 4.

Close-up of small-sample assay chamber, with $\mathrm{B}_{4} \mathrm{C}$ shield and cadmium liner removed, showing fissionchamber monitors and rotating semple bolder.

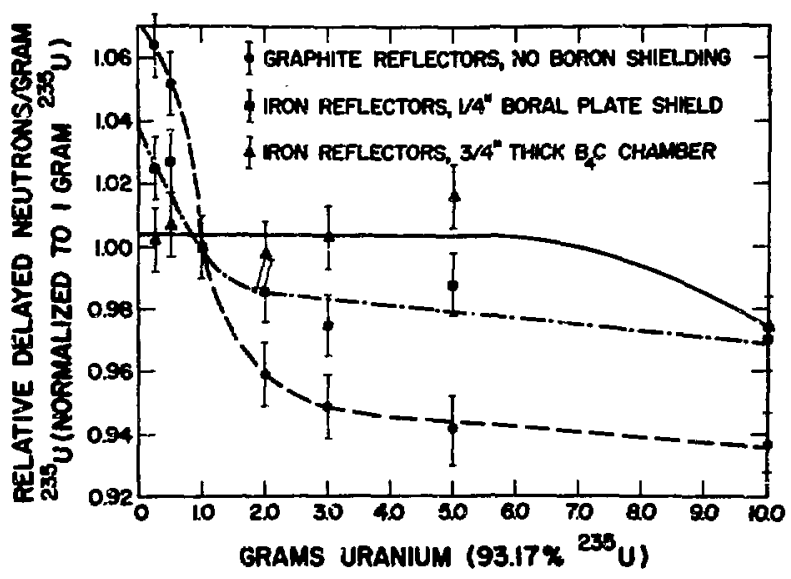

Fig. 5.

Comparison of linearity of delayed-neutron response usirg $B_{4} C$-sbielded assay cbamber witb response of previously used configurations for small-sample assay by subtbresbold neutron interrogation.

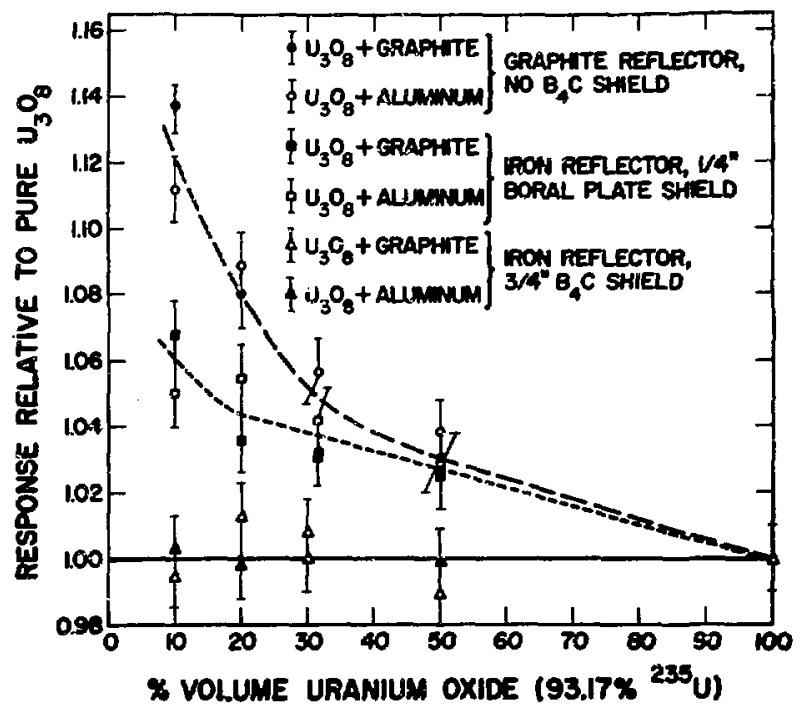

Fig. 6.

Delayed-neutron response of $1 \mathrm{~g}$ of enricbed uranium $\left(93.17 \% \%^{235} \mathrm{U}\right)$ in various quantities of grapbite or aluminum, using tbe new $B_{4} C$-sbielded assay cbamber and two previously used configurations for small-sample assay.

C. Measurement of the LASL Enriched-Uranium Inventory (R. H. Augustron, E. I. Whitted, and J. H. Menze:)

Active interrogation measurements of highly enriched uranium scrap in the fused "klinker" category have been completed. Based on the experience gained from these measurements using the sealed tube neutron source assay system, ${ }^{4}$ a larger campaign has been planned to complete analyses on all previously unmeasured items of uranium scrap in recovery-can geometry. This will involve handling approximately 300 separate itens and a large amount of data. Special attention is being given to presentation of the final results in order to facilizate their incorporation into the LASL S.S. material inventory system. Looking toward the goal of making Los Alamos a model of good safeguards and materials accountability, plans are under way to implement a full line of nondestructive assay equipment, together with calibration standards, at Ten Site, LASL, and thus to keep current on the measurement of all S.S. materials-feed, product, scrap and waste-in the LASL inventory.

A program of receiver measurements on OWR fuel elements has recently been iniciated as part of the LASL goal of keeping eurrent with a complete measured inventory. To date, A-1 has measured $60 \mathrm{MTR}$-type fuel elerrints received by Group P-2 for the LASL Omega West Reactor. In the future it is expected that all OWR fuel elements will be measured as they are received, prior 
to formal receipt of the material on AEC Transfer Form 741-this being another facet of good safeguards and materials accountability through prompt measurement of all receipts and shipments to assure a current and complete measured inventory.

D. Fissile Asay of Uranium-Thorium-Fluoride in TwoLiter Containers (A. E. Evans and J. L. Parker)

Eight 2-liter polyethylene containers of mixed fluorides of uranium and thorium (from Nuclear Materials and Equipment Corporation, Apollo, Penna.) were assayed for ${ }^{235} \mathrm{U}$ content using subthreshold neutrons from the A-1 Van de Graaff accelerator. Due to the low uranium-to-thorium ratio (ranging from $1 \%$ to $10 \%$ ) and high density of this material, subthreshold-neutron interrogation was considered the best and easiest way to assay these samples. A passive assay of the containers was made as a rough check on active-assay results.

The eight samples were assayed by interrogation with 35 -msec pulses of 350 to $630 \mathrm{keV}$ neutrons (generated by bombarding a $2 \mathrm{mg} / \mathrm{cm}^{2}$ lithium target with 2.35-MeV protons), and counting delayed neutrons in 40-msec intervals between pulses. An interval of $15 \mathrm{msec}$ was allowed between the bombarding and counting intervals for die-2way of "room-return" neutrons. A standard active assay configuration was used, consisting of a $B_{4} C$ low-energy neutron shield surrounding the sample, plus a fission-hhamber flux monitor inside of the shield. A standard A-1 neutron "slab detector" was used to measure the delayed-neutron response. Samples were rotated at $\sim 10 \mathrm{rpm}$ during assay. The assay setup was calibrated using $\mathrm{UO}_{2}$ standards (10\% and $93 \%$ enriched in ${ }^{235} \mathrm{U}$ ) mixed with graphite in 2-liter polyethylene bottles. The possible influence of thorium on the assay was checked by making up a seandard of $100 \mathrm{~g}$ of $93 \%$ enriched uranium in $1 \mathrm{~kg}$ of thorium oxide in a 2 -liter polyethylene bottle. This latter standard was found to assay $1.55 \%$ higher than $100 \mathrm{~g}$ of $93 \%$-enriched uranium in graphite, and the appropriate correction was applied to assay results.

The fluorine in the samples gave rise to neutrons from the ${ }^{19} \mathrm{~F}(a, n){ }^{22} \mathrm{Na}$ reaction, resulting in a background neutron count of from $4 \%$ to $10 \%$ of the delayed-neutron count in each sample.

Passive gamma assay of ${ }^{235} U$ content of the NUMEC U-Th-F containers was carried out as a rough check on active assay results. Since in all cases the contents ot the containers were essentially "black" to th is radiation, the measurement yielded a number proportional to the ratio of ${ }^{235} \mathrm{U}$ to total high-Z mass in the container. ${ }^{5}$ The ${ }^{235} \mathrm{U}$ content was then calcalated as the appropriate fraction of the total weight of the sample. In this case, the $185-\mathrm{keV}$ passive gamma measurement has an estimated accuracy of $\sim 10$ to 20\%; however, the further influence of sample inhomogeneities on passive gamma assay results could not be readily estimated.

Reaults of both active and passive assays are shown in Table 1, together with the fissile content originally indicated on the label of each bottle. Clearly the active assay method, with accuracy conservatively estimated as $\sim 5 \%$, is to be recommended for analysis of fuel materials in this category.

\section{TABLE I}

\section{RESULTS OF ASSAY OF TWO-LITER BOTTLES OF URANIUM-THORIL. HFLUORIDE MIXTURE}

(From Nuclear Materials and Equipment Corporation, Apollo, Penna.)

\begin{tabular}{|c|c|c|c|}
\hline \multirow{2}{*}{$\begin{array}{r}\text { NUMEC } \\
\text { Ident. No. }\end{array}$} & \multirow{2}{*}{$\begin{array}{l}\text { Lebel } \\
\text { Value }\end{array}$} & \multicolumn{2}{|c|}{${ }^{233} \mathrm{U}$ Content (g) } \\
\hline & & Astive Assay" & Passiye Assay ${ }^{b}$ \\
\hline SS 522 & 142 & 158 & 158 \\
\hline SS 555 & 93 & 79 & 88 \\
\hline SS 517 & 134 & 106 & 112 \\
\hline SS 1126 & 28 & 32 & 33 \\
\hline SS 635 & 6 & 39 & 31 \\
\hline SS 443 & 175 & 142 & 145 \\
\hline SS 553 & 97 & 47 & 51 \\
\hline SS 884 & 52 & 44 & 52 \\
\hline
\end{tabular}

E. Assay of Two-Liter Containers of Uranium-Thoriun Carbide (A. E. Evans and J. L. Parker)

Seven 2-liter containers of scrap from the HTGR fuel-fabricatica facility at the Gulf General Atomic Fuel Operations Division were assayed for fissile content using the delayed-neutron response method and the passive "segmented gamma scan" method.

Subthreshold ( 350 to $630 \mathrm{keV}$ ) neutrons from the A-1 Van de Graaff accelerator were used (as deseribed in the previous section) to interrogate and assay the 2-iter containers. The assay arrangement was calibrated using as standards 10,50, 100, and $200 \mathrm{~g}$ of $93 \%$-nriched uranium in graphite-filled, 2 -iter polyethylene bottles.

For the five lowest-density samples, results were checked by counting $185-\mathrm{keV}$ gamma rays from ${ }^{235} \mathrm{U}$ using the "segmented gamma scan" system. ${ }^{6}$ Gamma-ray absorption in the two highest density samples prevented accurate assay by gamma counting.

The results of the three LASL assays are shown in Table II together with the original label value on the containers. The passive gamma scan is expected to have an uncertainty of $\pm 10 \%$, while active assiny using neutron interrogation is believed accurate to within $5 \%$ (except in the case of Sample No. 1, for which a suitable standard was not available). 
TABLE II

ASSAY OF GULF URANIUM-THORIUM-CARBIRE MATERIALS

\begin{tabular}{|c|c|c|c|c|c|}
\hline \multirow[b]{3}{*}{ Sarnplc } & \multirow[b]{3}{*}{ Description } & \multicolumn{4}{|c|}{${ }^{235} \mathrm{u}$ Content (p) } \\
\hline & & \multirow{2}{*}{$\begin{array}{c}\text { Culf Con Atomic } \\
\text { Lalud Value }\end{array}$} & \multicolumn{2}{|c|}{ LASL Active Asory } & \multirow{2}{*}{$\begin{array}{c}\text { LASL } \\
\text { Pacive Aasy }\end{array}$} \\
\hline & & & $\operatorname{Ren} 1$ & $\operatorname{Run} 2$ & \\
\hline 1 & Graphite-coated fuel & $229.12 \pm 6.64$ & 248 & 250.5 & $\ldots$ \\
\hline 2$\}$ & particles, $\mathrm{ThU}=4.54: 1$ & $105.59 \pm 4.57$ & 109.3 & 108.4 & $\cdots$ \\
\hline 3 & Ground-up coater lintss & $33.53 \pm 3.35$ & 20.8 & 20.2 & $202 \pm 2$ \\
\hline 4$\}$ & & $20.49 \pm 2.05$ & 10.9 & 12.8 & $10.8 \pm 1.2$ \\
\hline 5 & 191 UThC fucl rods & $20.28 \pm 1.91$ & 19.7 & 20.15 & $18 \pm 4$ \\
\hline 6 & Ground-up bed converter & $13.97 \pm 1.4$ & 5.67 & 5.79 & 5.6 \\
\hline 7$\}$ & crucibles & $13.97 \pm 1.4$ & 5.67 & 5.87 & 5.6 \\
\hline
\end{tabular}

\section{MATERIALS ANALYSIS USING ISOTOPIC SOURCES}

A. In-plant Performance of ${ }^{252}$ Cf Fuel Rod Assay Systems (D. B. Smith, R. A. Forster and H. O. Menlove)

The calibration and initial in-plant.use of the ${ }^{252} \mathrm{Cf}$ fuel rod assay system at G.E. Wilmington was described in detail in the last progress report. ${ }^{7}$ This system continues in use at G.E. for the assay of BWR fuel rods. In addition, the four standard rods are periodically assayed as unknowns, and the standards data are sent to Los Alamos. Analysis of these data indicates that the calibration of the system has not changed significantly over the $\sim 5$ months that the assay system has been in use.

The original LASL ${ }^{252} \mathrm{Cf}$ fuel rod assay system was shipped to Westinghouse-Columbia for calibration ana evaluation for PWR fuel rod assay. This unit is similar to the unit at G.P. except for the addition of an extended memory to the Hewletr-Packard $9100 \mathrm{~B}$ calculator used to accumulate and reduce the assay data. The additional available menory permits more convenient calibration ard use of the system.

The calibration procedure at Westinghouse was similar to that previously described ${ }^{7}$ for BWR fuel rods at G.E. Westinghouse proviaed four calibration rods (see Table III)-two each of two different enrichments. The response of each of these rods was measured $\sim 30$ times in each of the four assay channels. The resulting data were used to determine (by means of non-linear least-squares regression techniques) the constants $a$ and $b$ in the function

$$
\mathbf{R}=\mathbf{a}\left(1-\mathbf{e}^{-\mathbf{b} U}\right),
$$

whare $\mathbf{R}$ is the background-corrected response of the fuel rod to the neutron interrogation and $U$ is the ${ }^{235} U$ content of the rods. The resulting calibration curve is shown in Fig. 7. For comparison, the calibration curve for BWR fuel rods at G.E. is also shown. The curve for PWR fuel rods deviates less from a straight line because the PWR rod has a smaller diameter than does the BWR rod, consequently there is less neutron self shielding.

After the calibration constants ( $a$ and $b$ ) were established, each of the standard rods was assayed in each channel an additional ten times. A statistical analysis of all data indicated proper calibration of the system; i.e., the mean value of the ${ }^{235} \mathrm{U}$ content of each standard measured in each channel did not differ statistically from the "known" ${ }^{235} \mathrm{U}$ content of the rod. The total ${ }^{255} \mathrm{U}$ mass assayed was $39.292 \pm 0.017(10) \mathbf{K g}$ : the "known" mass

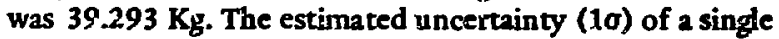
assay was $\sim 1.1 \%$ in gord agreement with the uncertainty expected due to the propagation of counting statistics (Fig. 8).

Cross talk between adjacent channels was measured to be $1.3 \pm 0.1 \%$ for the $2.545 \%$ enriched standards; i.e., this fraction of the response in any given channel is due to cross talk from adjacent channels. Cross talk from alternate channels was ton small to be measured. The assay system was calibrated with rods having the same nominal enrichment in all four channels. Since the unit will be used in this way (the same enrichment in all channsts and all channels full), cross talk will not istroduce any significant error into the assay. Other possible sources of error are similar to those discussed previously. 8

As in the assay of BWR fuel rods, assay of PWR rods took $\sim 35$ seconds for each group of four rois. With background measurement and rod handling, 400 to 600 rods/8-h day is a prictical assay rate. The precision of a

TAIL 11

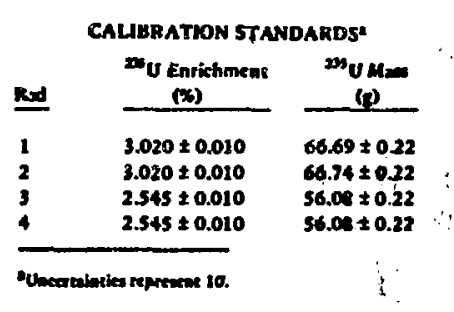




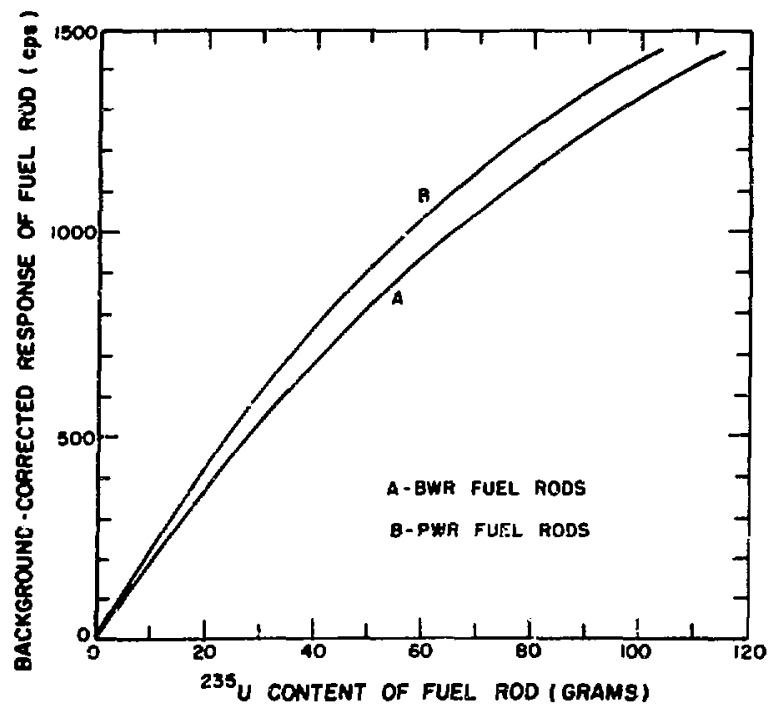

Fig. 7.

Comparison of calibration curves $\left(R=a\left(i-t^{-b}\right)\right)$ for assay of BWR fuel rods at G. E. (Wilmington) and PWR fuel rods at Wesiingbouse (Columbia).

sitzgle assay is dominated by the (propagated) counting statistics. This uncertainty due to counting statistics has been investigated in some detail as a furction of ${ }^{252} \mathrm{Cf}$ source decay (Fig. 9) and as a function of assay time (Fig. 10). It is seen in Fig. 9 that the precision of a single assay does not deteriorate seriously over the useful lifetime of the ${ }^{252} \mathrm{Cf}$ source. As shown in Fig. 10, the precision of an assay is rather strongly dependent on the assay time

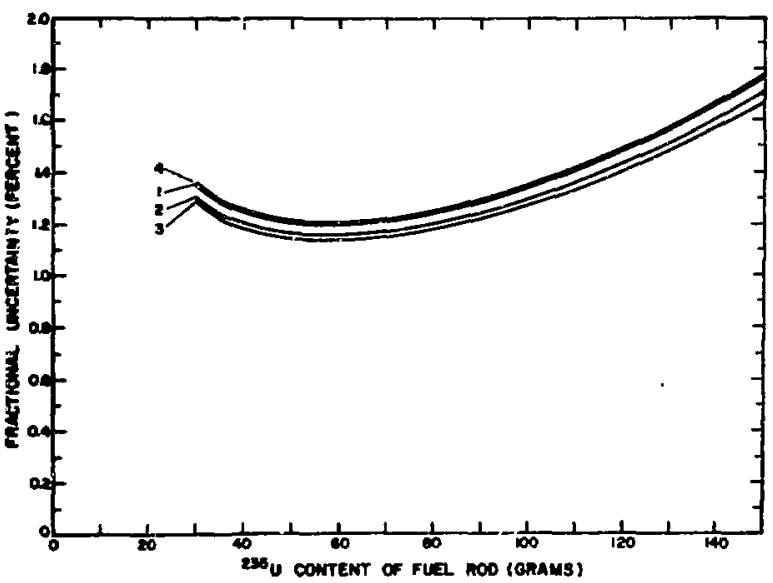

Fig. 8.

Calculated uncertainty due to counting statistics for the four channels of the fuel rod assay system at Westingbouse at the time of calibration (35-sec assay, 40-sec background count).

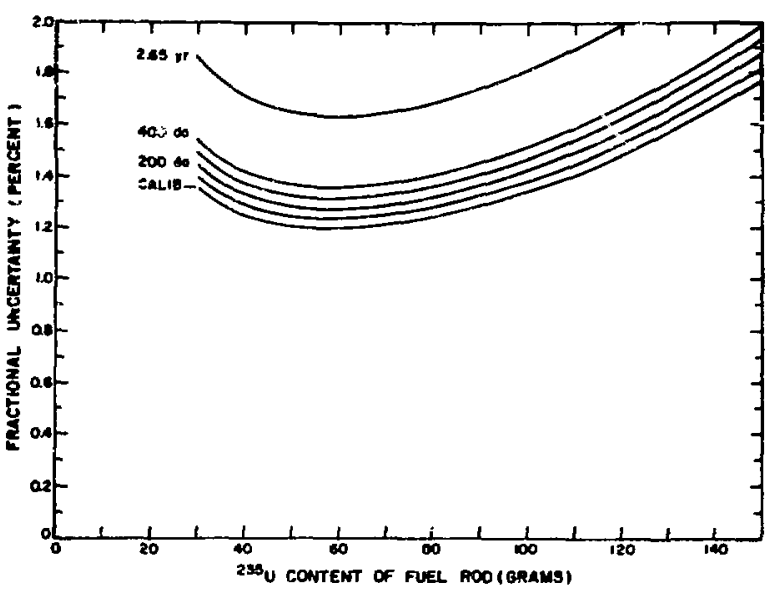

Fig. 9.

Calculated uncertainty due to counting statistics for several time increments after calibration of the fuel rod assay system at Westingbouse (cbannel one, 35-sec assay, 40-sec background count).

in the range $20 \mathrm{sec}$ to $1 \mathrm{~min}$; however, little is gained for times longer than $\sim 2 \mathrm{~min}$ for a fixed source size. A larger ${ }^{252} \mathrm{Cf}$ source would correspondingly decrease the assay time required to obtain a desired precision. Modifications to the system to obtain a pellet-to-pellet assay will require a larger source for rapid measurements and thus the precision for the total ${ }^{235} \mathrm{U}$ in the rod will be improved.

B. Thermal ${ }^{252}$ Cf Fuel Rod Assay System with Pellet-toPellet Scan (R. A. Forster and H. O. Menlove)

The thermal-neutron ${ }^{252} \mathrm{Cf}$ fuel rod assay system,

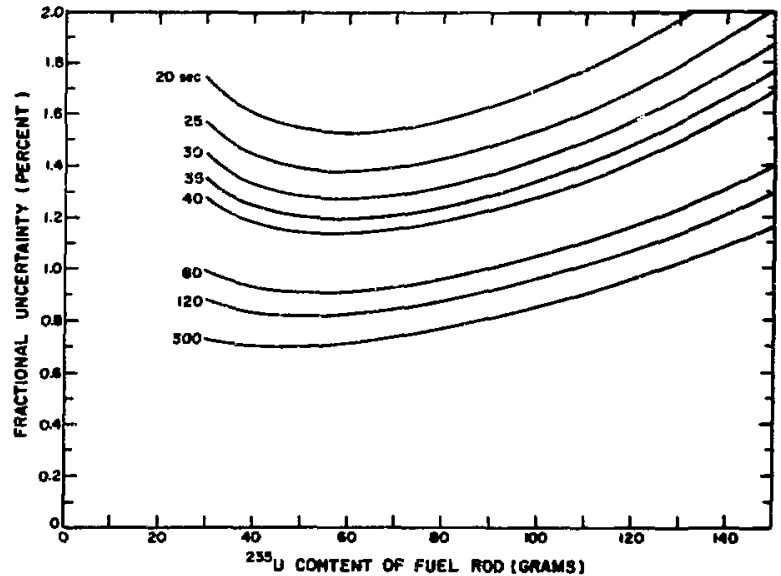

Fig. 10.

Calculated uncertainty due to counting statistics for several assay times in the fuel rod assay system at Westinghouse (channel one, 40-sec background count). 
used to measure total fissile content of reactor fuel rods, has been modified to measure also pellet-to-pellet variations in fissile content using delayed gamma-ray response as the fissile material signature. ${ }^{9}$ Since a high-intensity interrogation flux is needed for a rapid pellet-to-pellet scan, the present ${ }^{252} \mathrm{Cf}$ system has been modified to significantly increase the neutron flux in the fuel rod irradiation position.

A series of Monte Carlo calculations and measurements have led to the following modifications in the present assay system: 1) lengthening the moderator assembly in the direction of fuel rod travel, which results in a longer region of high thermal flux, 2) positioning the fuel rod channel closer to the ${ }^{252} \mathrm{Cf}$ source to take advantage of the higher intensity tlux near the source while still preserving a high fissile/fertile fission ratio $\left(\sim 10^{4}\right)$ to ensure accurate measurement of fissile content in the presence of much larger amounts of fertile material, 3) replacing the $\mathrm{D}_{2} \mathrm{O}$ in the moderator assembly with carbon to decrease cost while simplifying the fabrication and shipping, 4) changing the fuel channel position and replacing the $\mathrm{D}_{2} \mathrm{O}$ with carbon require that the ${ }^{4} \mathrm{He}$ detectors be shortened and displaced to one end of the carbon moderator to give a sufficiently large signal/ $/ 252 \mathrm{Cf}$ background ratio in the ${ }^{4} \mathrm{He}$ detectors, and 5) the addition of a small $\mathrm{NaI}$ detector near the exit port of each fuel rod channel to give pellet-to-pellet fissile content by counting fission-induced delayed gamma rays.

Preliminary measurements of delayed gamma signal rates have been made using a 1.5 in. diam $\mathrm{Nai}$ ietector with a through-hole for the fuel rod. Using a $500 \mu \mathrm{g}{ }^{252} \mathrm{Cf}$ source in a prototype thermal moderator ${ }^{10}$ the measured counting rate from the $\mathrm{Nal}$ detector was approximately $5 \times 10^{4}$ cps for a $5 \%$ enriched PWR type rod. A plot of the pulse-height spectra for the same rod, before and after irradiation, is shown in Fig. 11. The total induced activity in the ${ }^{235} \mathrm{U}$ was about $\mathbf{4 0}$ times greater than the passive signal rate from the $185-\mathrm{keV}$ peak alone. Also the induced signal rate is much greater than the protactinium background level and thus the pellet-to-pellet measurement is insensitive to the age of the $\mathrm{UO}_{2}$.

A thermal ${ }^{252} \mathrm{Cf}$ fuel rod assay system incorporating the modifications described above is being tested to evaluate pellet-to-pellet resolution and fuel rod throughput rates. It should be noted that the combined measurement of both prompt neutrons and delayed gamma rays or passive gamma rays gives the capability of assaying recycle fuel containing both ${ }^{239} \mathrm{Pu}$ and ${ }^{235} \mathrm{U}$.

C. Fast Neutron ${ }^{252}$ Cf Assay System (R. A. Forster, H. O. Menlove and J. L. Parker)

For active assay of samples with high fissile material density, fast neutron interrogation is required to insure high penetrability thru the sample. Unmoderated ${ }^{252} \mathrm{Cf}$ neutrons $\left(\overline{\mathrm{E}}_{\mathrm{n}} \sim 2 \mathrm{MeV}\right)$ provide to low a fissile/fertile fission ratio, so some moderation of the ${ }^{252} \mathrm{Cf}$ spectrum is required to improve this ratio, while also contributing to the biological shielding.

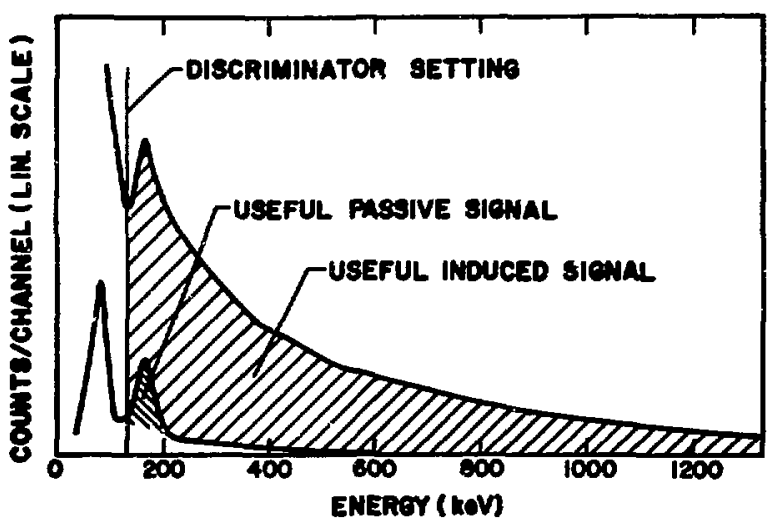

Fig. 11 .

Pulse-beight distribution of passive-gamma rays (bottom curve) and delayed-gamma rays (top curve) from fission reactions induced by a $500 \mu 8^{252} \mathrm{Cf}$ neutron source in a PWR-type fuel rod.

Neutron transport and Monte Carlo calculations were used to guide the design of a ${ }^{252} \mathrm{Cf}$ neutron moderating system for fast-neurron irradiation. DTF-IV calculations examined spherical moderator systems consisting of a moderating core surrounded by fast neutron reflectors and biological shielding. Some of the results are listed in Table IV. As expected, the hydrogenous materials lower the neutron energies too much for adequate penetration. Beryllium was examined as an intermediate moderating material with nickel and iron as fast-neutron reflectors. Table IV shows that nickel is clearly superior to iron as a fast-neutron reflector. The sample was located at $10 \mathrm{~cm}$ radial position to optimize simultaneously the signal and the fissile/fertile fission ratio.

After the basic materials were selected using the above results, several more time-consuming Monte Carto calculations were performed to optimize the actual nonspherical system shown in Fig. 12. Fig. 13, which shows the calculated neutron spectra for the system in Fig. 12 with and without the nickel cylinder, illustrates the importance of the nickel cylinder to the signal rate. The nickel provides $\sim 70 \%$ increase in total signal rate.

In order to count the fission reactions induced in the sample, a 5 in. by 5 in. $\mathrm{NaI}(\mathrm{Tl})$ detector is positioned near the ${ }^{252} \mathrm{Cf}$ shield to measure the delayed gamme rays from the sample. The NaI detector has a 2 -in. diam through-hole for the passage of the irradiated sample giving maximum geometric coupling. A tungsten sleeve was placed in the detector hole to reduce the low-energy gamma-ray background from the rod.

To determine the expected signal rates and signal/background ratios, an FFTF fuel rod segment was irradiated in the prototype moderator ${ }^{12}$ and then counted in the $\mathrm{Nal}$ detector using an irradiation-transfer-counting cycle corresponding to a continuous push rate of roughly 36 in./min for the rod. Figure 14 shows the net measured response from the FFTF rod as a function of detector bias energy. Also shown is the net signal/Pu rod back- 
TABLE IV

FISSION RATE CALCULATIONS FOR SPHERICAL ${ }^{252} \mathrm{Cf}_{\text {MODERATOR CONFIGURATIONS }}$

\begin{tabular}{|c|c|c|c|c|}
\hline \multirow[b]{2}{*}{$\begin{array}{l}\text { Moderator Material } \\
\text { and Shell Thickness }(\mathrm{cm})^{2}\end{array}$} & \multicolumn{2}{|c|}{$\begin{array}{c}{ }^{239} \mathrm{Pu} /{ }^{238} \mathrm{U} \\
\text { Fission Ratio } \\
\text { (Equal Masses) }\end{array}$} & \multicolumn{2}{|c|}{$\frac{{ }^{239} \text { Pu Fissions }{ }^{b}}{\mathrm{~g} \cdot \text { Source Neutron }}$} \\
\hline & $\frac{\text { Equal }}{100 \mathrm{eV}^{c}}$ & $\frac{s e s)}{1 e^{c}}$ & $100 \mathrm{eV}^{\mathrm{c}}$ & $1 \mathrm{eV}^{\mathrm{c}}$ \\
\hline $\mathrm{W}(1), \mathrm{CH}_{2}(1), \mathrm{Be}(6), \mathrm{Fe}(21)$ & 87 & 305 & $3.75 \times 10^{-5}$ & $1.32 \times 10^{-4}$ \\
\hline$W(1), \mathrm{CH}_{2}(2), \mathrm{Be}(5), \mathrm{Fe}(21)$ & 82 & 314 & $2.87 \times 10^{-5}$ & $1.16 \times 10^{-4}$ \\
\hline$W(1), \operatorname{Be}(7), \operatorname{Fe}(21)$ & 89 & 288 & $4.07 \times 10^{-5}$ & $1.32 \times 10^{-4}$ \\
\hline$W(2), \mathrm{Be}(6), \mathrm{Fe}(21)$ & 99 & 309 & $4.06 \times 10^{-5}$ & $1.27 \times 10^{-4}$ \\
\hline$W(3), \operatorname{Be}(5), \mathrm{Fe}(21)$ & 107 & 313 & $3.94 \times 10^{-5}$ & $1.16 \times 10^{-4}$ \\
\hline$W(1), \operatorname{Be}(7.5), \operatorname{Fe}(20.5)$ & 92 & 311 & $4.23 \times 10^{-5}$ & $1.43 \times 10^{-4}$ \\
\hline$W(1), \operatorname{Be}(7.5), \mathrm{Ni}(20.5)$ & 118 & 410 & $5.42 \times 10^{-5}$ & $1.88 \times 10^{-4}$ \\
\hline
\end{tabular}

The designation W(3), Be(5), $\mathrm{Fe}(21)$ corresponds to $23-\mathrm{cm}$ radius $W$ core surrounded by a 5-cm-thick layer of Be and $21 \mathrm{~cm}$-thick hyer of Fe. All assemblies are enclosed in additional biological shielding.

b.The fissionable material is located at 2 radius of $10 \mathrm{~cm}$ for all cases.

CThe energy corresponds to neutron cut-off energy in calculations.

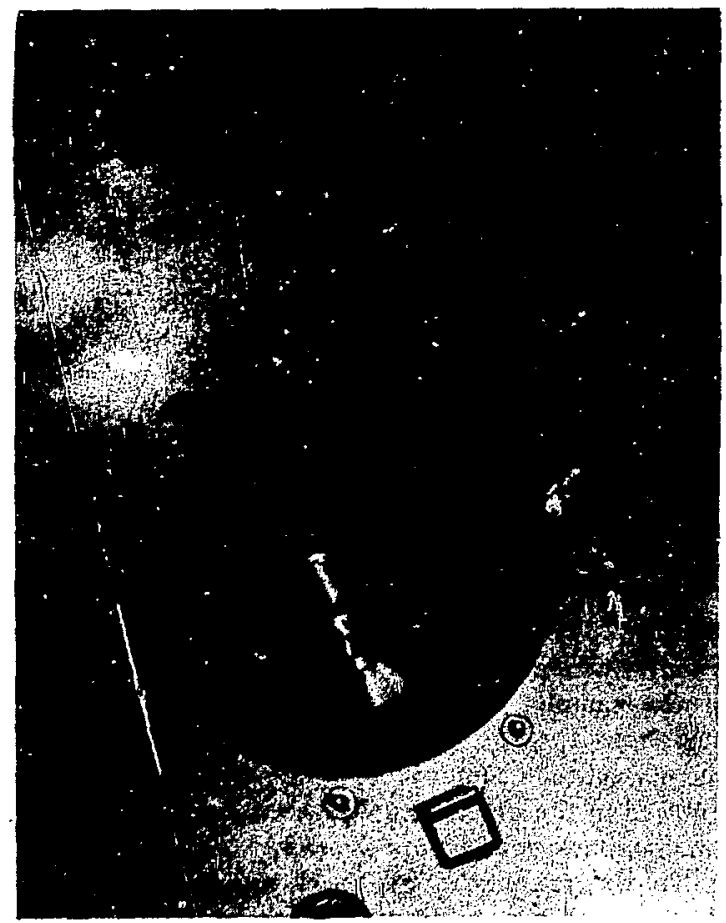

Fig. 12.

Pbotograpb of moderator and sbield assembly for a fast neutron ${ }^{252} \mathrm{Cf}$ assay system. The ${ }^{252} \mathrm{Cf}$ source is positioned in the center of the tungsten and the sample is placed in tbe nickel reflector for the neutron irradiation.

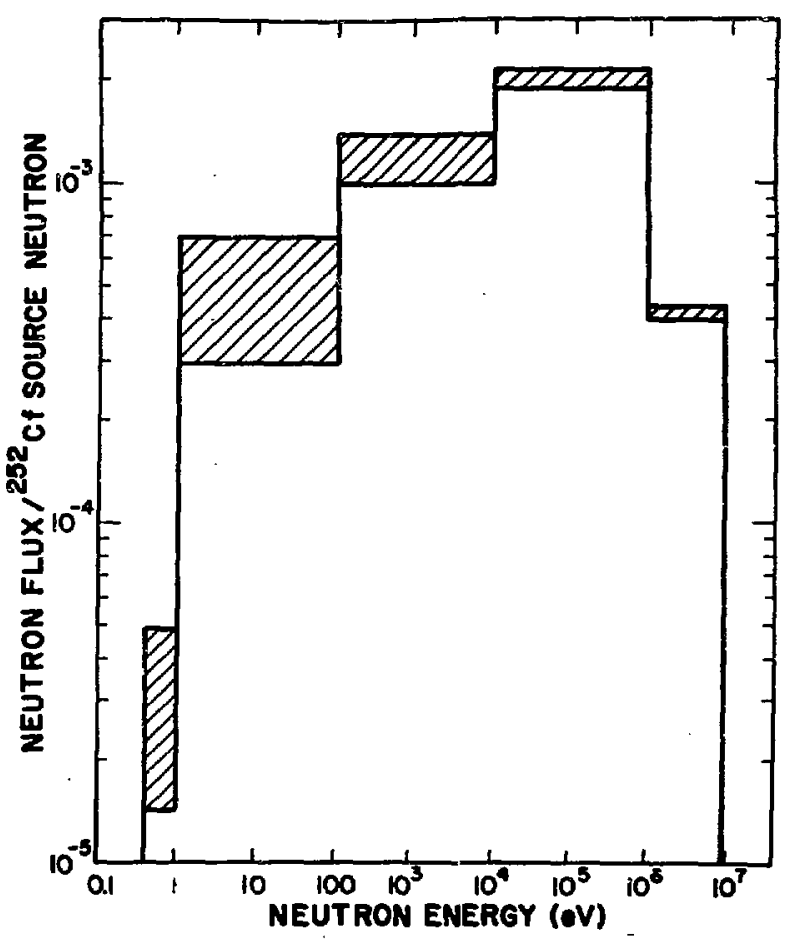

Fig. 13.

Calculated neutron spectra from a ${ }^{252} \mathrm{Cf}$ source for the system sbown in Fig. 12 witb (cross-batcbed area) and witbout the cylindrical nickel fast-flux tap. 


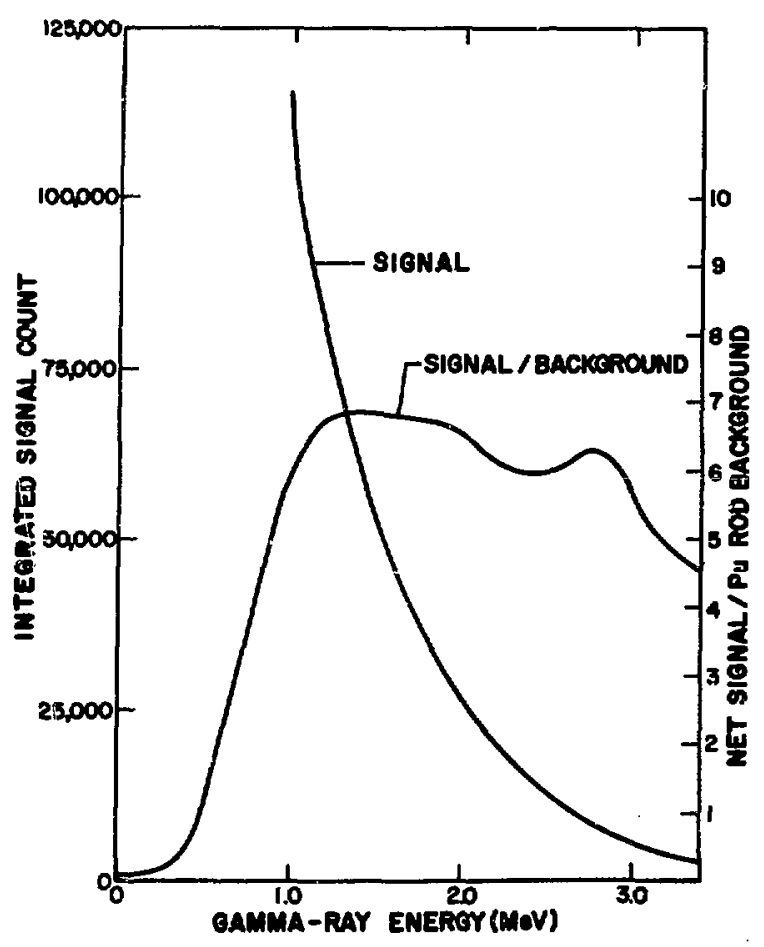

Fig. 14.

Integrated delayed-gamma-ray signal rates and signal-to-rod background ratios for an FFTF fuel rod after fast imadiation by a $500 \mu{ }^{252} \mathrm{Cf}$ source.

ground ratio which peaks at a bias enengy of $\sim 1.3 \mathrm{MeV}$. The integrated signal above this bias energy was $\sim 7 \times 10^{4}$ counts.

In addition to the total fissile active measurement it is possible to determine the pellet-to-pellet uniformity at the same time by counting the lower energy passive gamma rays from plut nium using the same Nal detector. For this purpose a collimation slit was cut in the tungsten sleeve centered in the $\mathrm{NaI}$ hole to expose approximately one pellet length at a time to the detector. When the collimation slit was set at $\mathbf{0 . 2 5}$ in. the measured signal rate in the 150 to $500 \mathrm{keV}$ energy window was $\sim 2 \times 10^{4} \mathrm{cps}$. Since the total fissile content of the rod is measured using the penetrating high-energy $(>1.2 \mathrm{MeV}$ ) induced gammaray signal, the low-energy passive signal is used only to confirm that all the pellets in the rod are from the same plutonium batch, and thus it is possible to use all of the signal from this wide enengy window.

The fast neutron moderater shown in Fig. 12 will be incorporated into an FFTF fuel assay system to be used at the WADCO facility.

D. Photoneutron Assay System Using ${ }^{124} \mathrm{Sb}_{\text {or }}{ }^{88} \mathrm{Y}$ (H. O. Menlove and R. A. Forster)

The Sb-Be assay system described previously ${ }^{11}$ has been modified to accomodate an ${ }^{80} \mathbf{Y}$ source and to facilitate fabrication. In order to handen the neutron interrogation flux, the amount of beryllium in the source was decreased and titanium was added inside the nickel reflector as shown in Fig. 15. Since tiranium has a larger elastic scatt-ring cross section than nickel at $\sim 26 \mathrm{keV}$ (the ${ }^{124} \mathrm{Sb}$ source energy), it will retum more of the high-energy source neutrons back into the central sumpisirradiation channel.

Rod-shaped sources of both ${ }^{124} \mathrm{Sb}$ and ${ }^{86} \mathrm{Y}$ are being fabricated to fit into the two scurce holes shown in Fig. 15 in order to evaluate the properties of these type systems. Because of the thick lead shielding required to protect personnel and detectors from the photon source (e.g., ${ }^{12}$ Sb), a system of the type shown in Fig. 15 is readily adaptable to the assay of "hot" samples and solutions; e.g., as might be found in a fuels reprocessing plant.

\section{E. Random Source Interrogntion System (J. E. Psley)}

Figure 16 shows the random source interrogation system $^{12}$ presently in use for assaying 2 -liter samples using fast plastic scintillation detectors. A tap view of the system is shown in Fig. 17. A random neutron source located inside the fast-neutron coincidence counter is used to interrogate the sampie containing ${ }^{235} \mathrm{U}$. A coincidence logic unit separates the counts produced by the random interrogation source from the coincidence neutrons from the induced fission events $i^{235} U$; thus the observed coincidence rate is proportional to the ${ }^{235} \mathrm{U}$ content of the sample.

Each plastic scintillation detector (see Fig. 16) hes three photomultiplier tubes and is shielded on the surface facing the sample with 2 in. of lead to reduce gammi-ray interference to the assay. The steel reflectors (Fig. 17) serve to increase the interrogating neutron flux. The coincidence efficiency of the system is $\sim 1.5 \%$. A cam located at he bottom of the counter produces the constant speed vertical translation of the neutron source. The cam actuator is linked to the rotating sample holder such that a single motor drives both sample rotation and source translation. Total system weight is $\sim 600 \mathrm{lbs}$; the instrument is mounted on wheels for easy mobility.

1. Coincidence Logic. The coincidence logic system is made entirely of EG\&G M-100 fast nuclear instrumentation components (Fig. 18). Two output channels are provided: 1) a "real + accidental" channel that records the sum of the actual coincidence counts from the induced fissions in ${ }^{235} \mathbf{U}$ plus any accidental coincidence counts caused by random events occurring within the coincidence resolving time, and 2) an "accidental" channel that records the number of accidentally produced coincidences. The difference between the "real + accidental" scaler reading and the "accidental" scaler reading is the number of real coincidences observed, which is proportional to the number of induced fissions in the ${ }^{25} \mathbf{U}$ (plus any background coincidence counts, e.8., from cosmic rays). 


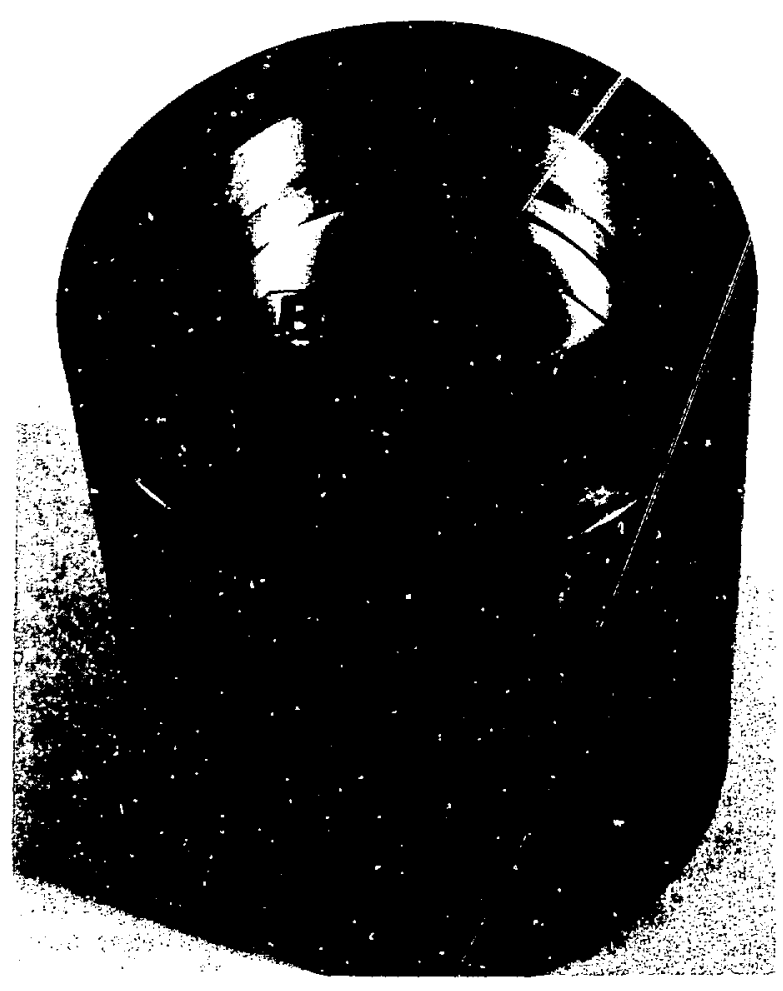

Fig. 15.

Neutron generating assembly for tbe pbotoneutron assay system using eitber ${ }^{124}$ Sb or ${ }^{88} Y$. Tbe pboton sources are placed on botb sides of tbe assay cbannel to create a symmetric neutron flux.

2. Marrix Material Corrections. A ${ }^{3}$ He detector is mounted inside the counter to correct for changes in neutron flux within the sample due to the presence of nonfissionable matrix material in the sample. If a sample contains a considerable amount of hydrogenous material, for example, the induced fission rate will be increased accordingly. The high-sensitivity ${ }^{3} \mathrm{He}$ detector monitors this thermal neutron flux and corrects for this matrix material effect.

To correct for the effest of matrix material on detector response, the ${ }^{252} \mathrm{Cf}$ source addition technique ${ }^{13}$ is used. Typically, the coincidence rate drops by a factor of $\sim 2$ when a sample with no matrix material is replaced by cne containing $0.6 \mathrm{~g} / \mathrm{cm}^{3}$ polyethylene. A small ${ }^{252} \mathrm{Cf}$ sponisneous fission source $\left(\sim 10^{4} \mathrm{n} / \mathrm{sec}\right)$ placed at the side of the sample (at midplane) at some convenient location within the counter suffices for the correction measurement. (This source is removed during the random source interrogation of the sample.) This technique works bezause the response of the system is nearly radially independent; i.e., it does not matter whether the source is located within the sample or near its outer surfact. The

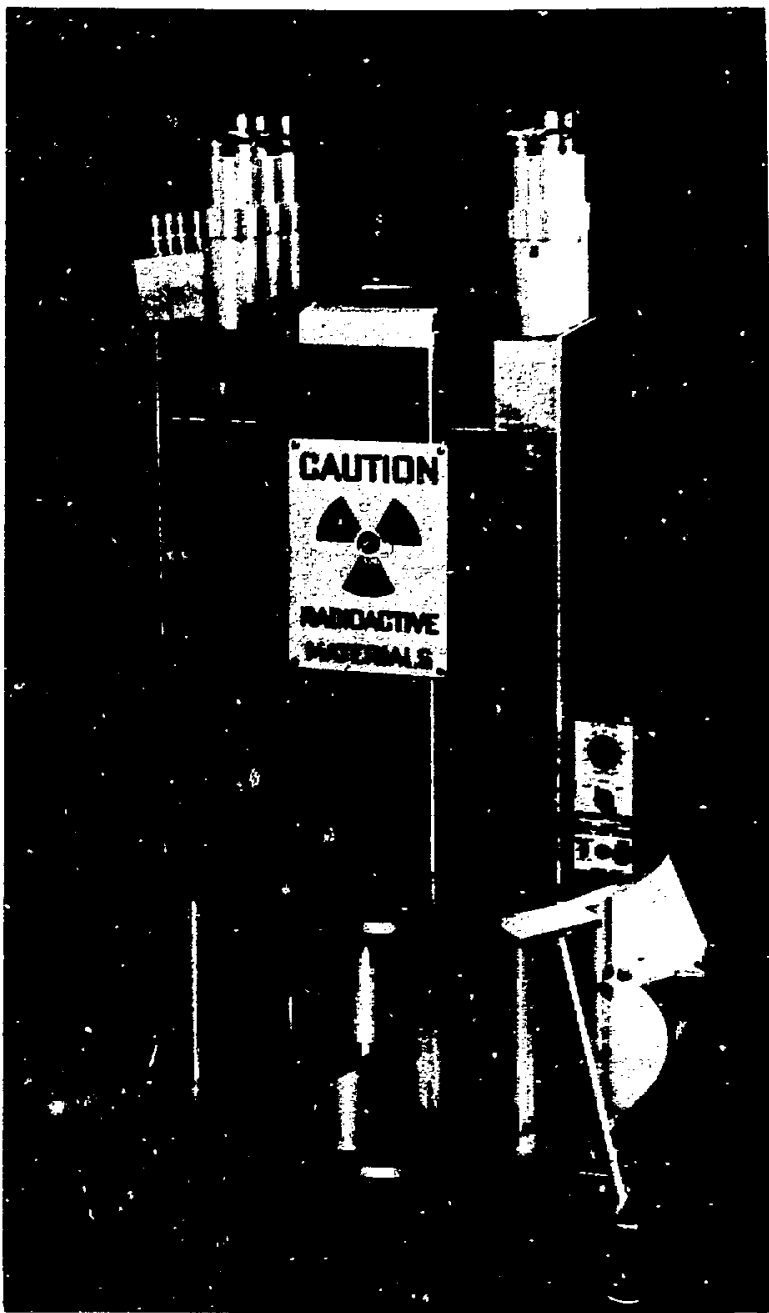

Fig. 16.

Random source-interrogation system.

resulting correction for matrix effects on the i zsponse of the cointer is good to a few percent, independent of the matrix material.

3. System Performance. Typical counting rates of the real + accidental and accidental scalers are shown in Fig. 19, for data taken with $22 \times 10^{5} \mathrm{n} / \mathrm{sec} \mathrm{AmLi}$ source and coincidence resolving time of 50 nsec. The observed background coincidence rate is due to cosmic rays and a small contribution from the neutron source. A calibration curve for the system, obtained using $\mathrm{U}_{3} \mathrm{O}_{8}$ samples in 2-liter bottles, is shown in Fig. 20. The "fast-neutron interrogation" curve employed the bare $\mathrm{AmLi}$ source, while the "thermal-neutron interrogation" curve was obtained by enclosing the source in a 1 th in. by 2 in. by $4 \%$ in. polyethylene block. Both curves have been corrected for neutron thermalization and absorption within the samples by the ${ }^{3} \mathrm{He}$ flux monitor. 


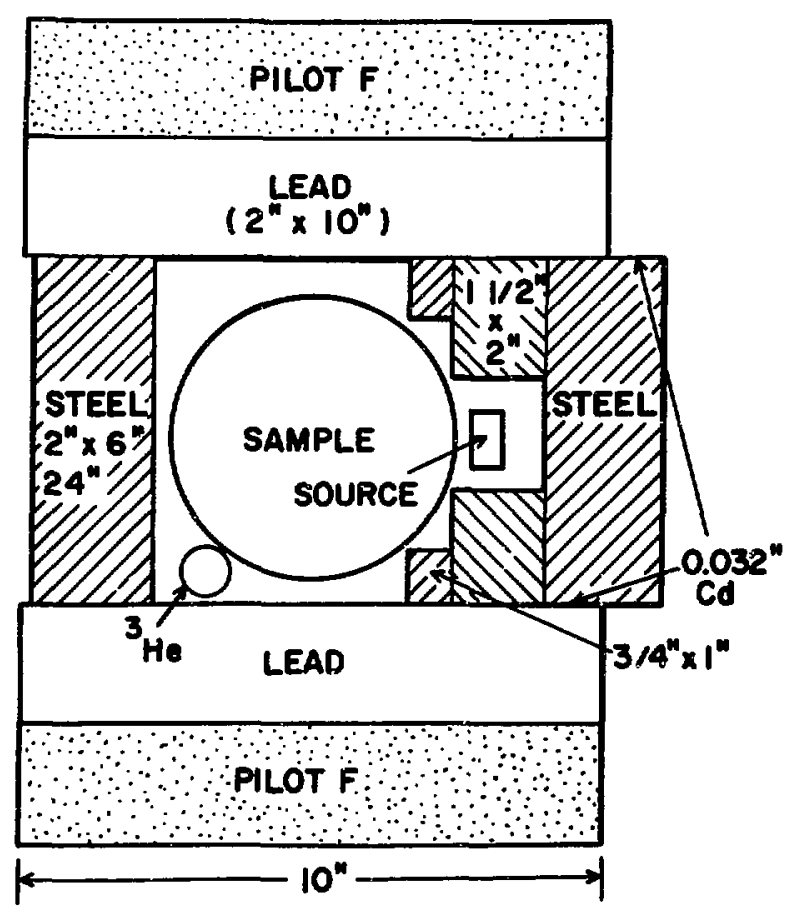

Fig. 17.

Sketcb of present random source-interrogation system.

Assay precision for 2ssay times of $100 \mathrm{sec}$ and $1000 \mathrm{sec}$ as 2 function of sample mass are shown in Fig. 21 for both thermal and hard spectrum interrogation. Sensitivity* of the system is $\sim 0.5 \mathrm{~g}^{235} \mathrm{U}$ and $\sim 3 \mathrm{~g}^{235} \mathrm{U}$, respectively, for the thermal and hard spectrum interrogation.

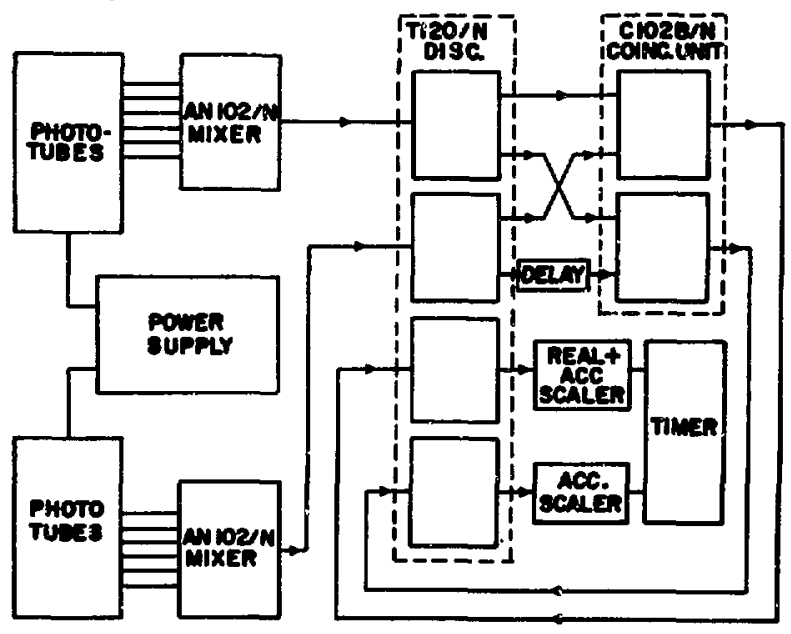

Fig. 18.

Logic unit made of EG\&G components.

The definition of censitivity used here is: that quantity of urenium whose net response in $600 \mathrm{sec}$ sany time is twice the standard deviation of the backgraund coincidence counts. (cf. $W$. J. Gallegher, BHO-674, p. 28 (1971.)

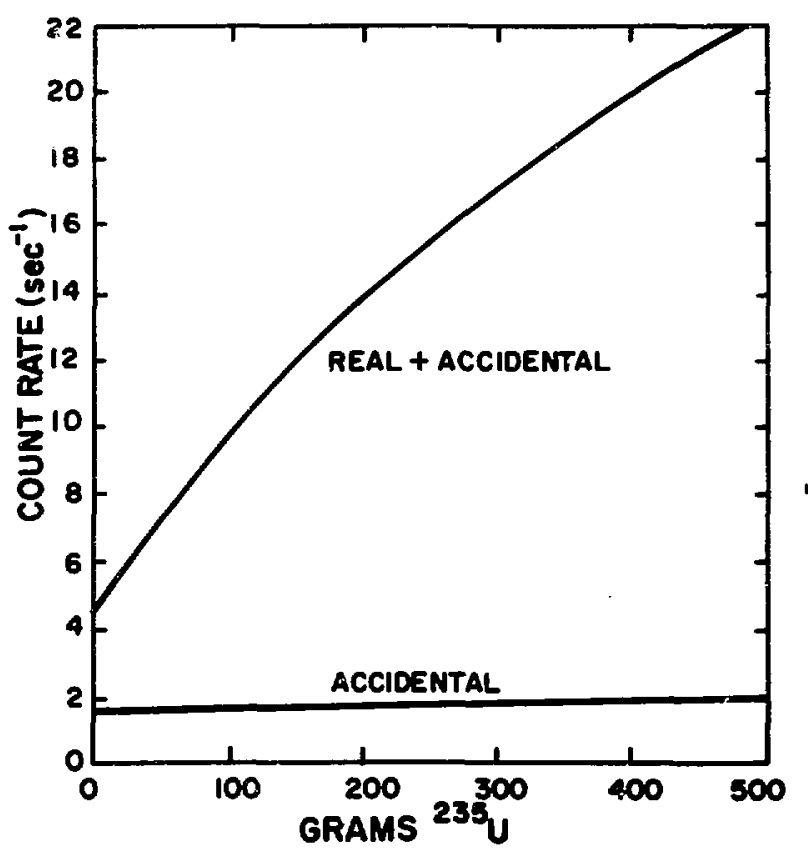

Fig. 19.

Counting rates of the real + accidental and accidemtal scalers for bard-spectrum neutros interrogation of ${ }^{235} U$.

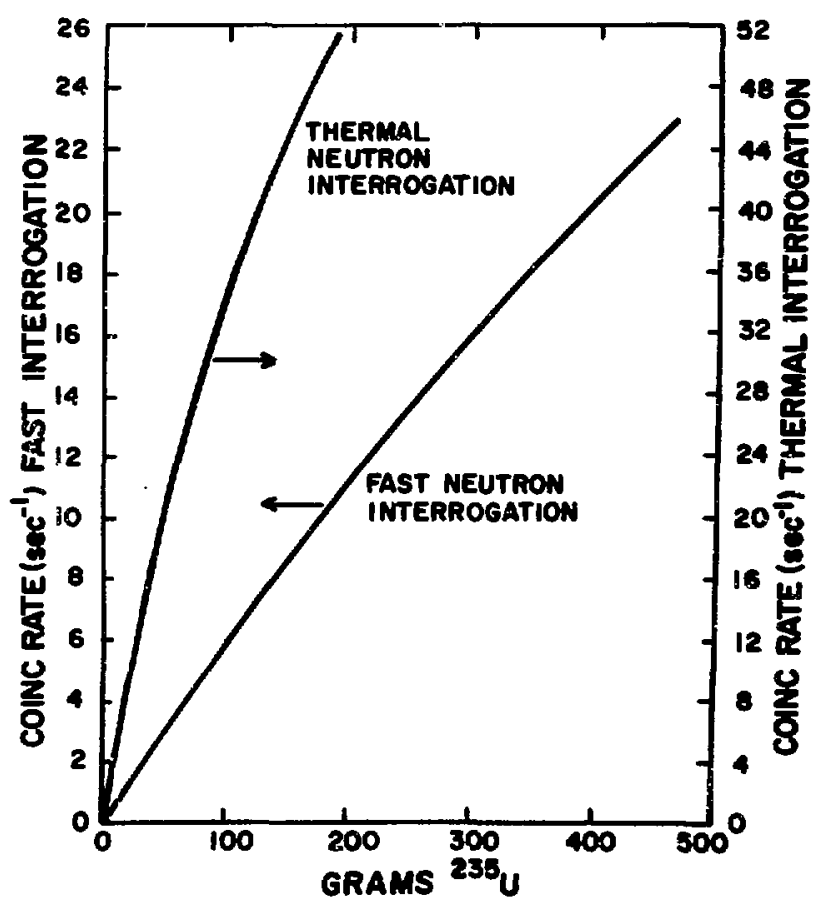

Fig. 20.

Calibration cuross for botb fast and tbermal neutron interrogation. Tbese cuenes bue been normalized to the ${ }^{3} \mathrm{He}$ flux monitor. 


\section{GAMMA-RAY AND X-RAY ANALYSIS APPLCATIONS}

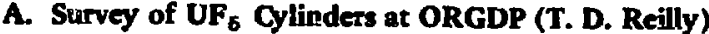

The field assay program at the Oak Ridge Gaseous Diffusion Plant included gamma measurements on the contents of a storage building for old $\mathrm{UF}_{6}$ cylinders. The building contained about 250 items in some 20 different containers ranging from small sample sylinders (3.5-in. diam by 10-in. high) to old product cylinders (14-in. diam by 48-in. high) from the early days of the facility. Limited information existed on the contents of this building and the condition of some of the containers would have made sampling difficult. Therefore, nondestructive measurements were requested to evaluate the contents before planning recovery or disposal. The goal was to provide "factor of two" type measurements for this purpose.

A $\mathrm{Ge}(\mathrm{Li})$ gamma scan system was moved into the building to perform the assay. All but the largest sizes of containers were rotated in front of the uncollimated detector. The activities measured were from the $185 \mathrm{keV}$ line of ${ }^{235} \mathrm{U}$, the $1001 \mathrm{keV}$ line of ${ }^{234 \mathrm{~m}} \mathrm{~Pa}\left({ }^{238} \mathrm{U}\right.$ daughter) and the $662 \mathrm{keV}$ line of ${ }^{137} \mathrm{Cs}$ (a common long-lived fission product present in many of the items in the building). A correction for the absorption of the ${ }^{238} \mathrm{U}$ gamma was made by calculating the absorption of 2 cylindrical mass of $\mathrm{UF}_{6}$ of the same diameter as the container. This procedure assumes that the $\mathrm{UF}_{6}$ is a uniform solid mass at the bottom of the cylinder and does not take into account the characteristic of $\mathrm{UF}_{6}$ for sublimation and random condensation throughout the cylinder. Thus, the procedure may overestimate the uranium content, particularly in cases where there is only a small heel. This procedure was supplemented by transmission measurements on about $20 \%$ of the cylinders. In the few instances in which other data were available, the agreement appears satisfactory.

These assays took two weeks to complete, including the movement and setup of equipment. They are an example of the type of routine assay which can be provided as part of a MONAL-based field assay operation. It is also a good example of a measurement problem that, due to the difficulty in sampling, lends itself to nondestructive analysis.

\section{B. Automated Pasaive Gamma-Ray Asay (L V. Eat)}

A Digital Equipment Corporation Model PDP-11/20 computer has been obtained for use in conjunction with a pulse-height analyzar for various prototype and routine passive assay systems. The computer was obtained with 8192 words of read/write memory, teletype, dual DECtape drive, and an interface to A-1's Geoscience pulseheight analyzer. Supporting software will consist of an interpretive programming system, similar to BASIC or FOCAL, that will allow users to write specialized programs for pusleheight analyzer control and date reduction.

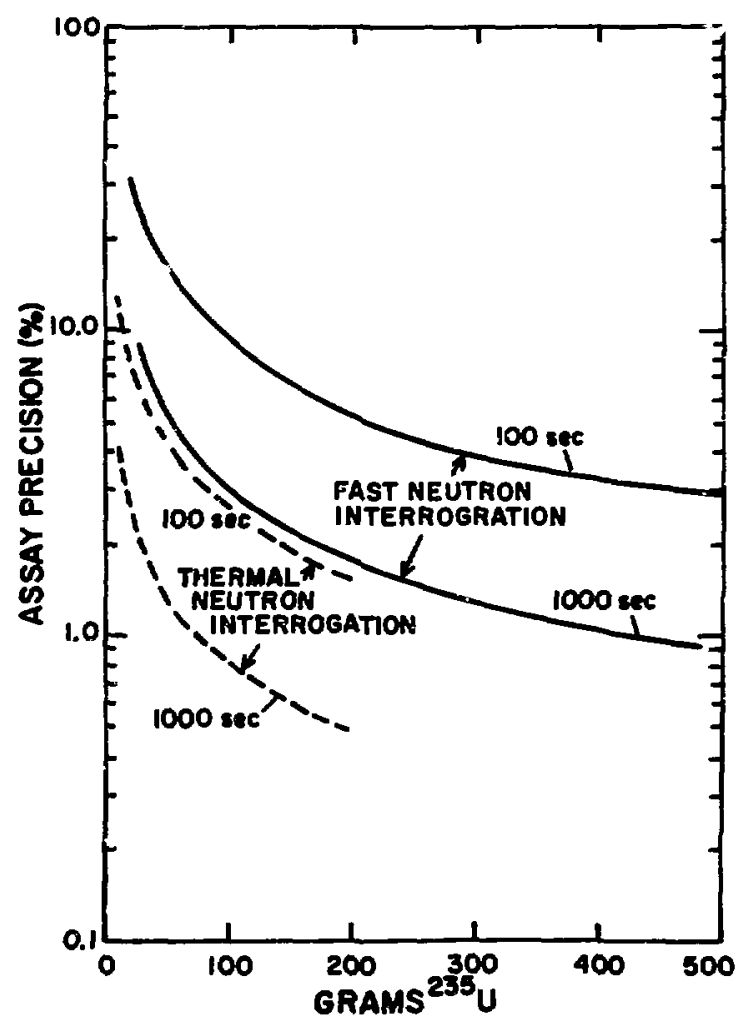

Fig. 21.

Assay precision for amious amounts of uranium using the LASL random source interrogation system witb a $2 \times 10^{5} \mathrm{n} / \mathrm{sec}$ AmLi source and $50 \mathrm{nsec}$ coincidence resolving time. Assay precision is defined as the ratio of the standard deviation of the assay to the assay value.

This system will be primarily a dedicated on-line system with rather specialized capabilities, as opposed to the PDP-9/L system with its more extensive VO and programming capabilities that can be used either for on-line data acquisition or for off-line work such as den analysis, plotting, etc.

C. Trace Element Analysis Using X-ray and ProtonInduced X-ray Fluorescence (C. J. Umbaryer and J. J. Malanify)

Work is continuing on the development of methods for elemental analysis of small samples using the sechnique of $x$-ray fuorescence. Sensitivities of one partper-million are easily attainable with proton induced fluorescence using the A-1 Van de Graff aceelerator. $X$ ray induced fluorescence using radionctive sources or $x$-ray cubes has sensitivities routinely approaching 15 parts-per-million. These sensitivities are obrained in short 
date collection times and with little or no sample handling; thus the method lends itself to the measurement of many samples in a short time with correspondingly low cost per analysis. By simple concentration of liquid samples, effective sensitivities of the order of several parts-per-billion can be achieved.

Figures 22 and 23 show typical results when uraniumspiked urine and water samples $(0.05 \mathrm{ml})$, respectively, are bombarded with $2.25 \mathrm{MeV}$ protons. The uranium $L x$ rays show up clearly above background. $X$-ray

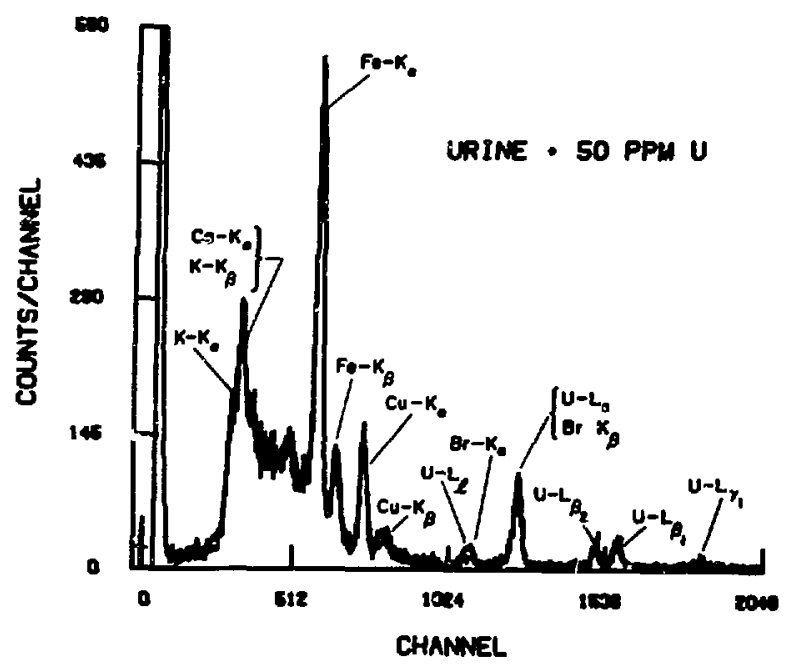

Fig. 22.

$X$-ray spectrum from $2.25 \mathrm{MeV}$ protons bombarding a buman urine sample with $50 \mathrm{ppm} U$. Filters are used to reduce the intensity of low-energy $x$ rays. filters were positioned between the detector (Ge(Li)) and the tangets to reduce the intensity of lower-energy $x$ rays from lighter elements in the sam ple. Sensitivities for these particular samples are $\sim$ one part-per-million, which is well below the MPC level for natural uranium in water (32 parts-per-million for public water systems). Concentrating the sample would permit detection sensitivities of $\sim 1$ part-per-billion; this is sufficient for determination of natural uranium in urine samples well below the toxic level (0.15 parts-per-million).

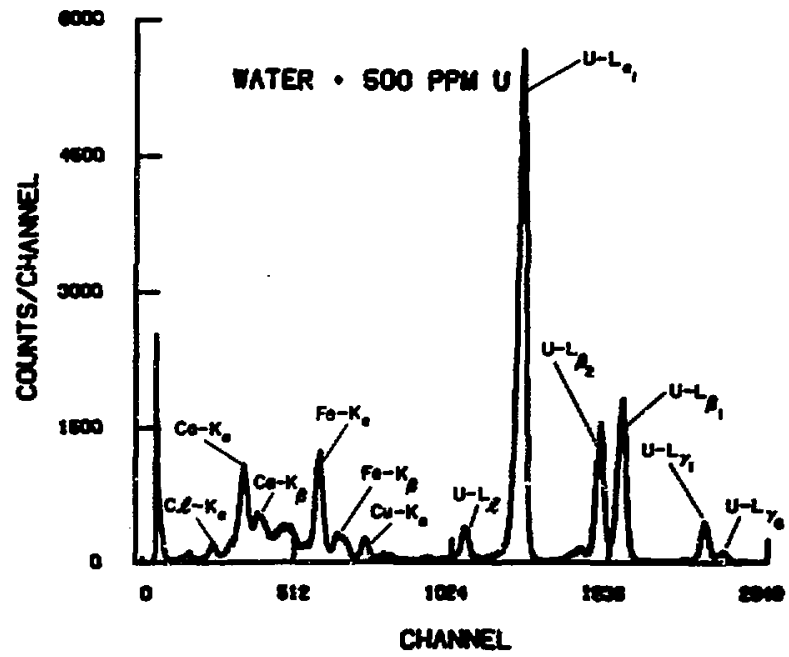

Fig. 23.

$X$-ray spectrum from $2.25 \mathrm{MeV}$ protons bomberding a vater sample witb $500 \mathrm{ppm} U$. Filturs are waed to reduce the intensity of low-enengy $x$ rays.

\section{DETECTOR AND DNSTRUMENTATION DEVELOPMENT}

A. Sealed-Tube Neutron Ganeratior Bveluntion (R. H. Augustson and E. I. Whitted)

The active neutron interrogation system utilizing a sealed-tube $14-\mathrm{MeV}$ neutron generator ${ }^{14}$ has been used on 2 routine basis to measure items in LASL's enriched uranium inventory. Thus far, the tube has been operated for $200 \mathrm{~h}$ in the pulsed mode, with no difficulties arising either in the tube or the pulsed high-voltage power supply. The neutron yield has exhibited a slow increase during this time, as predicted by the manufacturer. Minor problems with the control console which oecurred early in the test program were corrected by upgrading marginal components. No further problems have arisen in approximately $150 \mathrm{~h}$ of pulsed operation. The sealed tube sasay system has proven to be operationally simple, effective and straightforward; the system promises to be well suited for certain types of routine nondestructive assuy messurements by plant personnel in industry. The fresent sealedtube evaluation program-at LASL and Gulf United Nu- clear Corporation, Wood River Junction, R.I. - is directed toward a complete, compact, active asay system uains the sealed-tube source for highly penetrating neutron intertogation and assay in nuclear industrial facilities.

\section{B. UF 6 Enrichment Monitor for Puel Reprocesing Mrat (T. D. Reilly)}

Group A-1 is participating in an AEC-IAEA afeguards experiment being conducted at General Blectric's new Midwest Puel Reprocessing Plant (MPRP) at Morris, llinois. The LASL commitment involves construction of a continuous enrichment monitor to be inatilled in the UF $_{6}$ loadout area at MFRP. This monitor will use a $\mathrm{Nal}$ detector to ineasure the $185-\mathrm{keV}$ famme ray from ${ }^{20} U$. The detector will be fitted to a flowthrough chmber defining a fixed volume of liquid UF $_{6}$ for mearurement. For this situation the intensity of the $185 \mathrm{keV}$ line is directly proportional to the amount of ${ }^{225} U$ in this 
volume and hence directly proportional to the ${ }^{235} \mathrm{U}$ enrichment of the $\mathrm{UF}_{6}$ product.

The detector will be shielded from extraneous gamma rediation and cooled in order to function in the 80 to $90^{\circ} \mathrm{C}$ environment of the valve box. The output from the detector is amplified and fed to two single channel analyzer-scaler combinations. One of these is set to count the activity in the $185 \mathrm{keV}$ region; this activity consists of the ${ }^{235} U$ signal plus Compron background from higher energy gamma rays. The other single channel analyzer is set to count a region just above the $185 \mathrm{keV}$ window and is used to correct out Compton background. The scalers will be interfaced to the MFRP sufeguards computer thus providing a continuous readout of the ${ }^{235} U$ enrichment in the UF 6 loadout lines. The system is scheduled for installation and testing at MFRP in March, 1972.

\section{Coincidence Asay Systems for LASL Pu Procesaing Facility (DP-Site) U. R. Foley)}

The $4 \pi$ neutron coincidence assay system ${ }^{15}$ developed and constructed by Group A-1 for the LASL plutonium processing group (CMB-11) will be used for routine assay of plutonium content of 30-gallon scrap barrels. This system has been installed, complete with water-filled shield tanks, in the new plutonium nondestructive assay station (located in Bldg. 312) at DP-Site, and is presently undergoing calibration and testing. In addition to this barrel assay system, a smaller 2-liter-capacity neutron coincidence counter has also been provided for the DPSite plutonium assay station. This counter consists of two rings of ${ }^{3} \mathrm{He}$ detectors (32 total) moderated by polyethylene and is completely surrounded by 2 6-in. thick water shield. ${ }^{16}$ The total neutron detection efficiency of the 2-liter counter is $\sim 30 \%$, the coincidence efficiency $\sim 10 \%$, and neutron die-away time $\sim 35 \mu$ sec. This counter will be useful for ascay of small amounts of plutonium in high $(a, n)$ active samples because of the high neutron efficiency and relatively short neutron die-away time of the detector. Each of these asany systems $(30 \mathrm{zal}$ and 2-liter) is provided with its own complete set of electronic logic and counting equipment thus enabling completely independent operation of each.

\section{PDP-9/L Computer-Baned Data Acquisition Syatem (L. V. East)}

The pulse-height data acquisition and analysis programs have been modified to better utilize the additional memory and 1/O devices that have been added to the PDP-9/L. 8192 words rather than 4096 words of memory are now used for data storage allowing acquisition of a single $\mathbf{8 1 9 2}$ channel spectrum or simultaneous acquisition of two independent spectre containing up to 4096 channels each. A two-user pubeheight analyais program has aleo been written that will allow two independent exper- iments to run simultaneously. One experimenter has at his disposal the main teletype, display, light pen, control panel, and line printer; the other experimenter has use of a remote teletype and storage display. Also, each experimenter can store and retrieve data from his own DECtape which is "locked-out" from the other user.

A two-user version of the FOCAL * interactive programming system mentioned previously ${ }^{17}$ was found to allow an unacceptable amount of interaction between users. A considerable amount of programming effort has gone into rewrising portions of the FOCAL interpreter in order to sorrect this problem. Other changes have also been made that should increase the general usefulness of the FOCAL programming system on Group A-1's PDP-9/L.

Hardware has been completed and tested that will allow data from remote scalers to be read by the computer. Supporting software has also been written to allow scaler data to be read by FORTRAN programs vir a subroutine call and by FOCAL programs via an external function call.

\section{E. LASL Interaction with Commercial Manufacturess of Nondestructive As:ay Instruments}

Group A-1, LASL, has received many inquiries and some followup visits from representatives of the U.S. nuclear instrument munufacturing industry regarding commercial marketing of LASL-designed nondestruetive assay equipmerit. Considerable effort has been dewoted to presentation of the state-ofthe-art of NDA techniques and equipment, as well as to ascisting instrument manufacturess in evaluating the practical usefulness and market potential for NDA equipment in various types of facilities within the nuclear fuel cycle. Every effort has been made to provide the requested technical information, method intercomparisons, consultation on field applications, ete., to all U.S. instrument manufacturers who are seriously interested in producing commercial NDA instruments.

As new or upgraded nondestructive aseay systems are developed and prototype units tested by LASL, the resulting technical information and performance specifications will be made directly available to requesting U.S. nuclear instrument manufacturers who will commercially market such equipment. To date, the vendors who have ensfirmed their intent to supply LASL-designed equipment are Canberra Industries, Meriden Connecticut; Eberline Instrument Corporation, Santa Fe, New Mexico; and Nuclear Chicago, Texas Nucless Division, Austin, Texas. The nuclear analyais research group (A-1), LASL, will continue to ascist NDA instrument manufacturers, and through munufacturers the instrument users, in order to assure the most effective utilization of commercial NDA equipment in all types of nuclear facilities.

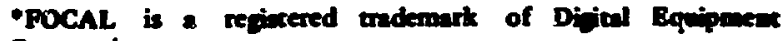
Corporation. 


\section{MONALBASED FIELD ASSAY OPERATIONS}

In early October, LASL's Mobile Nondestructive Assay Laboratory (MONAL) was moved to the Oak Ridge Gaseous Diffusion Plant; the extended visit will involve all three AEC facilities at Oak Ridge: K-25, Y-12, and ORNL. Operaticins to date involve K-25 only; in February work will begin on material from Y-12.

Operations at K-25 have been divided into three general categories: scrap measurements, effluent monitoring, and eascade operations. About 150 containers of scrap from purge traps and various recovery operations were assayed using neutron coincidence counting and

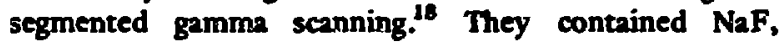
$\mathrm{Al}_{2} \mathrm{O}_{3}, \mathrm{MgF}_{2}$, incinerator ashi, and impure oxide. Instruments were calibrated with standards fabricated by K-25. The ash and impure oxide are similar to the material measured during the MONAL visit to NLO last winter. ${ }^{19}$ Due to earlier limited avilability of the LASL neutron coincidence counter this instrument will be returned to ORGDP for further evaluation as a potential production tool. A system for measuring the ${ }^{235} \mathrm{U}$ enrichment of recovery materials will be set up in conjunction with the coincidence counter. Active neutron $25 s a y$ was performed on a sampling of 20 -gal drums of used barrier material and compressor blades. Measurements were also made on some old $\mathrm{UF}_{6}$ product cylinders; this work is described earlier in this report (See Section III-A).

The work on effluents was undertaken in order to advise K-25 plant personnel responsible for air and water monitoring. A waste-water activity monitor based on the FIDLER ${ }^{20}$ detector was demonstrated at the plant. This consists of a 1/8 in. Nal detector with $20.010 \mathrm{in}$. window to measure low energy $x$ rays. It can provide a continuous readout of the radionctivity level in a liquid stream and can be designed to actuate an alarm or shut a valve if the level exceeds a preset limit. The device has a sensitivity of about 0.2 MPC. A trial system will be loaned to ORGDP for installation in the recovery plant effluent system to cvaluate its ability to provide better knowledge of plant effluents.

An x-ray fluorescence system capable of measuring uranium in water down to one part-pertbillion was also demonstrated at the plant. This involved a lowenengy thin window $\mathrm{Ge}(\mathrm{Li})$ detector to measure gamma-excited fluorescence $x$ rays. The system is reasonably eary to operate and provides an asany in two hours or les (ascuming some sample concentration).

The work on cascade operntions will be carried on during the month of January. For these measurements several gamma-insurumented carts have been constructed. Part of the orixinal K-25 building, K-306, had been ahut down and evacuated several years ago and a sumple survey of this unit will be undertaken to verify the cleanliness of the equipment.
A variety of measurements will be made in the operating cascade. These will include evaluation of equipment to measure uranium buildup in purge traps to determine when traps should be unloaded, tests of energysensitive gamma instrumentation to detect and extimate freeze-out and holdup of $\mathrm{UF}_{6}$ in the cascade, and asistance to plant personnel involved with measurement of UF $_{6}$ enrichment in the gas stream.

\section{REFERENCES}

1. J. H. Menzel, A. C Dumrose, and R. H. Augutwon, Lo Alamos Scientific Laboratory report LA-4705-MS, P. 1-2 (1971).

2. J. H. Menzel, A C Dumrose, and R. H. Aututoon, Los Alumos SCientific Liboratory report LA-4794-MS, P. 1-3 (1971).

3. A. E. Evans and J. J. Malanify, Los Alamos Seientic Laboratory report LA-4794-MS, p. 5 (1971).

4. R. H. Alzustron and $E$. 1. Whicted, las Alamos Scientife Laboratory report LA-4794-MS, p. 7 (1971).

5. T. D. Reilly, R E. Walton, and J. L. Rerter, Lo Alame Seientific Lbontory report LA-6005-MS, p. 19 (1970).

6. J. L. Purker, T. D. Reilly, D. A. Smith, R. B. Writon, and I. V. Bux, Los Alemos Scientific Leboratory report LA-470SMS, pp. $12-15$ (1971).

7. H. O. Menlore, R A. Fouter, D. A. Suing and It M Forehand, Los Alamos Sciendific Lboratory report LA. 4794-MS, pp. 8-10 (1971).

8. I. O. Meniore and R. A. Rorter, Los Alumo Scientife Labontory report LA-4605-MS, Pp. 8-12 (1970).

9. H. O. Meniove, T. D. Reily, and R. B, Whion, los Alumes Scienific Laboratory report LA-470s-Mis, Fe. \&) (1971).

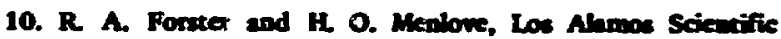
Lobocamy repart LA-4523-MS, p. 12 (1970).

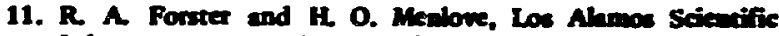
ibontory report LA-4794-iss, p. 10-12 (1971).

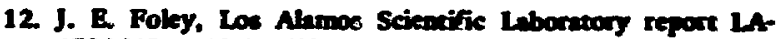
4794-aS, p. $12(1971)$.

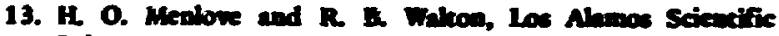
Inboratery report LA-4A57-ins, p. 2 (1970).

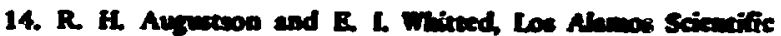
Labanour report LA-4794-ins, p. 7 and 22.23 (1971).

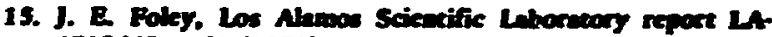
4705-MS, P. 20 (1971).

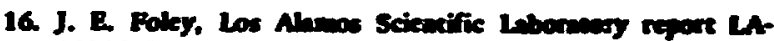
8794-ins, 12 (1971). 
17. L. V. East, Los Alamos Scientific Laboratory report LA4794-MS, p. 27 (1971).

18. J. L. Parker, T. D. Reilly, R. B. Walton, D. B. Smith, and L. V. East, Los Alamos Scientific Laboratory report LA-4705MS, Pp. 12-15 (1971).
19. J. E. Foley and J. L. Parker, Los Alamos Scientific Laboratory report LA-4605-MS, pp. 34-37 (1970).

20. J. F. Tinney and J. J. Koch, UCRL-50007-67-3, Hazards Control Progress Report 29, p. 15.

\section{PUBUCATIONS}

1. G. R. Keepin, R. L. Bramblett, and W. A. Higinbotham, "Development of Techniques and Instrumentation for Non destructive Assay of Fissionable Materials and Field Assay Experience," paper presented at the Fourth United Nations Intermational Conference on the Peaceful Uses of Atomic Energy, September 6-16, 1971, Genev, Switzerind.

2. J. H. Menzel, "Real Problems-Real Solutions," paper presented at the Symposium on Implementing Nuclear Safeguards, October 25-27, 1971, Manhattan, Kansis.

3. R. B. Walton, R. H. Augustson, L. V. East, A. E. Evans, J. E. Foley, R. A. Forster, G. R. Keepin, J. J. Malanify, H. 0. Menlove, J. H. Menzel, J. L Parker, T. D. Reilly, D. B. Smith M.M. Thorpe, and C. R. Weisbin, "Nondestructive Analytical Techniques for Materials in the Nuclear Fuel Cycle," paper presented at the IAEA Symposium on Analytical Methods in the Nuclear. Fuel Cycle, Nov. 28-Dec. 3, 1971, Vienm, Autria.

4. L. V. East, J. L. Parker, R. D. Reilly, and R. B. Walton, "Camma-Ray Scanning System for Barrels Containing Plutonium Waste," presented at the IEEE 1971 Nuclear Science Sympoxium, Nov. 3-5, 1971, Sen Francisco, Californis.

5. L. V. East, "Yet Another Photopenk Analysis Program for the PDP-9 Computer, "paper presented at the 1971 Fall DECUS Symporium, Nov. 10-13, 1971, San Francisco, California.
6. D. B. Smith, R. A. Forster, and M. M. Thorpe, "Criticality Considerations in the Nondestructive Assay of Nuclear Material", Trens. Am. Nucl. Soc., 14, 678 (1971).

7. N. N. Kaushal, E. J. Winhold, R. H. Augustson, P. F. Yergin, and H. A. Medicus, "Absolute Neutron Yields and Enegy Spectra from 18 Targets Bombarded by 55 and $85 \mathrm{MkV}$ Bremsstrablung," Jo. of Nucl. Energy, 25, 91 (1971).

8. J. J. H. Menet, E. E. Gross, J. J. Malanify, and A. Zucker, "Total-Reaction-Cross-Section Mezsurements for 30-60 MeV Protons and the Imaginary Optical Potential," Phys. Rev., $4 C$, 1114 (1971).

9. H. S. Plendl, D. Robson, C. J. Umbarger, D. F. Burch, and A Richter, "Total Activation Cross Section Ratios at the $(3,3)$ Resonance for $\left(\pi^{+}, \pi N\right)$ Reactions on ${ }^{19} \mathrm{~F},{ }^{33} \mathrm{P},{ }^{63} \mathrm{Cu}$, and 6 Zn," Proc. Internatl. Seminar on Pion-Nucleus Interactions, Sept. 1971, II-7, Strasbourg, France.

10. D. A. Close, R. C. Bearse, and C. J. Umbarger, "Study of the ${ }_{\mathrm{Mo}}\left(p, \eta^{95}\right.$ Tc Reaction from Ep $=2.4-3.0 \mathrm{MeV}$," Bull. Am. Phys. Soc., 10, 1170 (1971).

11. H. S. Plendl, D. Robson, C. J. Umbarger, D. F. Burch, and A. Richter, "Activation Cross Sections and Ratios for $(\pi, \pi N)$ and $\left(\pi^{+}, \pi N\right)$ Reuctions on $T=0$ Nuclei at the $(3,3)$ kiesonance," Bull. Am. Phys. Soc., 10, 1174 (1971). 